\title{
Valide Sultanların Kurduğu Vakıfların Kadına Yönelik Sosyal Hizmetleri
}

Musa SAHIN ${ }^{1}$

N. Ebrar KAYA ${ }^{2}$

\section{Özet}

Toplumda yardımlaşma ve dayanışma duygularının temelinde hayat bulan vakıflar birçok alanda hizmet vermiş, vermeye de devam etmektedir. Eğitim, gıda, sağlık, barınma, sosyal yardımlaşma, istihdam vb. birey hayatıyla iç içe birçok alanda vakıf hizmetleri sunulmuştur. Böylelikle farklı şartlara sahip bireylerin aynı toplumda birlik beraberlik içinde yaşamaları hedeflenmektedir. Ayrıca kurulan vakıflar; yollar, köprüler, çeşmeler, okul, cami, hamam vs. gibi nice hizmetler ile yaşanılan mekânın gelişimine katkı sağlayarak sosyal katalizör rolü üstlenmişlerdir. Osmanlı toplumunda oldukça önem kazanan bu müessese birçok alanda varlığını sürdürmüş, günümüz toplumunda da örnek alınabilecek hizmetlere ilham olmuştur. Sosyal güven ve dayanışmanın bir esası olarak toplumlarda hayat bulmuştur.

$\mathrm{Bu}$ makalede amaç, toplumda farklı sosyal tabakaların birbirleri ile kaynaşmasında vakıf aracılığıyla kadının, kamusal alanın inşasına katkısını ve kadına yönelik sosyal hizmetlerin neler olduğunu açıklamaktır. Araştırmada literatür çalışması yapılmış; veriler, alandaki yazılı kaynakların yanı sıra Ankara ve Samsun Vakıflar Genel Müdürlüğünün arşiv defterlerinden örnek vakfiyeler incelenerek toplanmış ve yorumlanmış; sosyal hizmet açısından vakıfların koruyucu, önleyici ve problem çözücü işlevleri ve hizmetleri belirlenmiştir. Elde edilen sonuçlar kadının toplumsal alanda etkin bir rol aldığı; sosyal sorumluluk alanına etkin bir şekilde katıldığını göstermektedir.

Anahtar Kelimeler: Kadın, Valide Sultanlar, Vakıf, Sosyal Sorumluluk, Sosyal Hizmet

\section{Social Services of Foundations Established by Sultanas}

\section{towards Women}

\section{Abstract}

The foundations finds life on the basis of cooperation and solidarity in the society have served in many areas, and they continuetogive. The foundation services has been presented in many areas in touch with individuals such as education, food, health, housing, welfare, employment and so on. Thus, individuals with different conditions is planned to live in unity in the same community. More over the foundations assume the role of social catalyst by contributing to the development of the living space with many services such as roads, bridges, fountains, schools, mosques, baths, etc. This institution which gained importance in Ottoman society has been inspired to services that may be taken as samples in today's society. It has found life in society as a basis of social trust and solidarity.

The purpose in this article is to explain the contribution of woman to the construction of the public arena for the merging of the different social strata with each others in the society by means of the foundation and also to declare what are the social services towards woman. In the research the literature review was conducted; the data were collected and interpreted by examining the written sources in the field, as well as examining the sample foundation certificate-charters from the archive books of the General Directorate of Foundations of Ankara and Samsun; the protective, preventive and problem-solving functions and services of the foundations were identified in terms of the social services. The results obtained indicate that woman has taken an active role in the social field and effectively participates in the field of social responsibility.

Key Words: Women, Sultana and, Foundation, Social Responsibility, Social Services

\footnotetext{
${ }^{1}$ Doç. Dr., Yalova Üniversitesi, İIBF, Sosyal Hizmet Bölümü, musasahin@yalova.edu.tr ${ }^{2}$ Yalova Üniversitesi, İ̈BF, Sosyal Hizmet Bölümü Yüksek Lisans Öğrencisi, nebrarkarakaya@gmail.com
} 


\section{Giriş}

İnsanın doğası gereği yardım ve iyilikte bulunma düşüncesi her dönem bireyleri yönlendirmiş, ihtiyaç sahiplerinin ihtiyaçlarını karşılama noktasında hayat bulmuştur. $\mathrm{Bu}$ bağlamda gerçekleştirilen bu yardım ve iyilikler; bireyin şahsi hayatı yanında aile hayatında da beklenen rolü sağlıkla gerçekleştirmesinde etkin olmuştur. $\mathrm{Bu}$ etkilenme toplumun yapısına da yansıyarak refah toplumlarının oluşmasına salık vermiştir. Bireylerle başlayan bu yardımlaşma ve dayanışma duygusu halka topluma yayılmış böylelikle vakıf müessesesi3 meydana gelmiştir. İnsan ihtiyaçları yanında hayvanların dahi ihtiyaçları düşünülerek Türk Tarihinde sayısız vakıflar kurularak; Ateş'in ifadesi ile "Yurdumuz adeta bir vakıf cenneti haline gelmiştir" (Ateş, 1995: 25).

Osmanlı toplumunda kadın konulu birçok kitap yazılmış, makaleler hazırlanmıştır. Ancak hazırlanan çoğu çalışmada Osmanlı kadınının gerçek durumu objektif olarak yansıtılamamıştır. Bunun yanında konu ile ilgili vakıf kuran şahıslar; idari, ekonomik, mimari açıdan incelenmiş sosyal hizmet bağlamında ise değerlendirmelere çok az yer verilmiştir. Tülây Duran'ın editörlüğünü yaptığı; Tarihimizde Vakıf Kuran Kadınlar- Hanım Sultanlar-, Can Alpgüvenç'in; Hayırda Yarışan Hanım Sultanlar, İbrahim Pazan'ın; Padişah Anneleri, Eserleriyle Valide Sultanlar, Nazif Öztürk'ün; Türk Yenileşme Tarihi Çerçevesinde Vakıf Müessesesi eseri ve Fanny Davıs'in; Osmanlı Hanımı 1718'den 1918'e Bir Toplumsal Tarih adlı kitapları bu alandaki değerli çalışmalardır. Bunun yanında; Samettin Başol ve Mevlüt Çam'ın; “Osmanlı Devleti'nde Kadınlara Yönelik Kurulan Vakıflar" adlı çalışmaları, Hasan Yüksel'in; Osmanlı Toplumunda Vakıflar ve Kadın çalışması ve Özlem Soyer'in Kadın Vakıfları: Kütahya Örneği Yüksek Lisans Tezi de bu alandaki nadir çalışmalardandır.

Sosyal hizmet eksenli çalışmaların yürütüldüğü vakıf müesseseleri sayesinde toplum refahı sağlanmıştır ki vakıf kurucu kadınların rolü dikkat çekicidir. Osmanlı toplumu ile ilgili yapılan çalışmalara baktığımızda4 iddia edilenin aksine kadına verilen değer ve kadının toplumdaki rolü açıkça görülmektedir. Bu araştırmada Osmanlı toplumundaki kadın; vâkıfe (kadın vakıf kurucu) perspektifinden ele alınmıştır. Kadının Osmanlı vakıf sistemindeki rolünü sosyal hizmet anlayışıyla açıklaması bakımından bu araştırma diğerlerinden farklı bir özelliğe sahiptir.

\footnotetext{
3 Vakıf, sözlükte durma, durdurma, hareketten alıkoyma ve hapsetme anlamlarına gelmektedir. Hukuki bir sözleşme yönü bulunan vakfin terim olarak anlamı ise; bir kişinin taşınır veya taşınmaz mallarını, hiçbir dış etki altında kalmadan, sırf kendi rıza ve isteği ile mülkiyetinden çıkarıp, Allah'a yakın olma ve hayır işleme gayesiyle yine kendisi tarafından belirtilen dini, hayri ve toplumsal şart ve hizmetlerin yerine getirilmesi için ebedi olarak tahsis etmesi işidir (Yediyıldız, 1982: 16-18). Kurulan vakıfların hangi şartlara göre çalışacağını gösteren belgeye ise vakfiye denmektedir. Vakıf müesseseleri asırlardan beri sosyal ve ekonomik hayat üzerinde derin tesirleri bulunan müesseselerdir. Osmanlının ilk dönemlerinde itibaren varlık göstermiş, sosyal hayatın düzeninde önemli rol oynamıștır. (Köprülü, 1983: 351-380)

${ }^{4}$ Osmanlı Kadın Hareketi/Serpil Çakır, Osmanlıda Kadın/Meral Altındal.
} 


\section{Kuramsal Çerçeve}

Osmanlı kadını, toplumda fakir ve varlıklı iki sosyal tabakanın birbirleri ile kaynaşması ve barış içinde yaşamasını sağlayan vakıf (Sınger, 2004: 104-105) sistemi içinde etkin bir rol almıștır. Bu bağlamda araştırmanın amacı; toplumun ihtiyaçlarına yönelik kurulan vakıflarda kadının rolünü, kadınların kurduğu vakıfların sosyal hizmet açısından işlevlerini ve yaptığı hizmetleri belirlemek; kadının toplumdan dışlandığı iddiasına da açıklık getirmektir.

Araştırmada Osmanlı kadınının kurmuş olduğu vakıflar, kadınlar için kurulmuş vakıflar ve kadınlara yönelik hizmetler içeren vakıflar tespit edilmiştir.

Literatür çalışmaları sırasında -üzülerek ifade etmek gerekir ki- çoğu kaynakta Osmanlı kadını; aciz, değersiz, toplumdan tecrit edilmiş, toplumda kabul görmeyen, dışlanan bir role sahip şeklinde anlatılmaktadır. ${ }^{5} \mathrm{Bu}$ bağlamda makalemizde problem olarak şunlar ele alınmıştır;

Problem: Osmanlı toplumunda kadının kamusal alandan dışlanıp dışlanmadığı, toplumdan tecrit edilip edilmediği, eş ve annelik dışında bir rolü olup olmadığı ve değersiz bir meta olarak görülüp görülmediğini tartışmaktır.

Hipotez: "Osmanlı toplumunda kadın kamusal alanın etkin bir aktörüdür. Vakıflar bu etkin rolün ifa edilmesinde kurumsal bir işlev üstlenmektedir.

Yöntem: Araştırma teorik bir çalışmadır. Kaynaklara dayalı bir açıklama öngörülmüştür. Vakıf sistemi içinde kadının hem hizmet alan hem de hizmet üreten rolü yani vakıf kuran girişimci rolü ele alınmıştır.

Veri toplama süreci: Vakıf konulu kitap ve makaleler taranmıştır. Hem Osmanlıca kaynaklar hem de güncel kaynaklar taranmıș; ek olarak Samsun Vakıflar Genel Müdürlüğü arşiv defterleri incelenerek vakıf kuran kadınlar tespit edilmeye çalı̧ıılmışır. Ayrıca Eyüp Belediyesi ve Eyüp Kültür Sanat Merkezi müdürlüğü ile görüşülerek Eyüp'teki vakıflar hakkında bilgi alınarak doküman talebinde bulunulmuştur. Yazılı kaynaklardan yararlanma yönteminde konuyla ilgili süreli ve süresiz yayınlardan, YÖK Dokümantasyon Merkezi'nden, İstanbul İslami Araştırmalar Merkezi Kütüphanesi'nden ve Yalova Üniversitesi Kütüphanesi'nden, Yalova İl halk Kütüphanesi'nden, Samsun Ondokuz Mayıs Üniversitesi Kütüphanesi'nden, Samsun İl Halk Kütüphanesi ve İlkadım ilçe Kütüphanesi'nden, Samsun Vakıflar Genel Müdürlüğü ve Ankara Vakıflar Genel Müdürlüğünden yararlanılmıştır. . Ayrıca, Samsun Vakıflar Genel Müdürlüğü ve Ankara Vakıflar Genel Müdürlüğü ile görüşülerek defter kayıtları ve örnek vakfiyeler incelenmiştir.

Kaynakların büyük bir çoğunluğunu kütüphane malzemesi oluşturmaktadır. Bu çalışmalar içinde özellikle Sipahi Çataltepe' nin İslam-Türk Medeniyetinde Vakıflar, Fanny Davıs'in; Osmanlı Hanımı, Hasan Yüksel'in; Osmanlı Toplumunda Vakıflar Ve Kadın çalışmalarını belirtmekte fayda vardır. Basılı kaynaklarda kütüphane kullanılmış, arşiv belgelerinin temininde Vakıflar Genel Müdürlüğü ile elektronik yazışmalar yapılmış ve Samsun Vakıflar Bölge Müdürlüğü defterlerinden yararlanılmıştır.

\footnotetext{
${ }^{5}$ Osmanlı Kadın Hareketi/Serpil Çakır, Osmanlıda Kadın/Meral Alındal, Türkiye'de Kadın.
} 
Verilerin analiz süreci: Elde edilen veriler çeşitli gruplara bölünerek değerlendirilmiştir. Veriler, kadınların kurduğu vakıflar, erkeklerin kadın hizmetlerine yönelik kurduğu vakıflar, kadınlara yönelik vakıf hizmetleri ve son olarak Osmanlı toplumunda kadının sosyal hizmet alanındaki rolü başlıkları ile sınıflandırılmıştır. $\mathrm{Bu}$ bağlamda kadınların sosyal hayatta ne kadar aktif rol aldıkları, topluma olan katkıları tespit edilmiş, kadınlar için kurulan vakıflarla da kadına verilen değere dikkat çekilmeye çalışılmıştır. Veriler; kadınların kurduğu vakıflar, erkeklerin kadın hizmetlerine yönelik kurduğu vakıflar, kadınlara yönelik vakıf hizmetleri ve Osmanlı Toplumunda kadının sosyal hizmet alanındaki rolü başlıkları altında açıklanmıştır.

\section{Bulgular}

Vakıf, Osmanlı Toplumunda kadının toplumsal süreçlere katılımında ve sosyal sorumluluk almasında firsat eşitliği sunmuştur. Sosyal sorumluluklara katılma hakkı herkese açık bir sosyal haktır. Bu hakkın kullanılmasında vakıf etkin bir sosyal araçtır.

Vakfın kökenine baktığımızda vakıf kurmada; hem kültürel hem de dini kaynaklarda erkekler kadar kadının da aynı sosyal davranışa hak kazandığını görürüz. Gerek geleneğimizde gerekse dini kaynaklarda toplumsal sorumluluk kadın ve erkek için eşittir. Yardımlaşma ve dayanışma sorumluluğu erkek ve kadın için aynıdır. Bir tercih ve ayrım söz konusu değildir. Şartları taşıyan kadınların erkekler gibi etkin bir şekilde vakıf kurdukları kaynaklarda görülmektedir.

Allah, Kur'an-1 kerimde iyilik yapmayı ve iyilikte yarışmayı kadın ve erkek her inanana farz kılmıştır. İyilikte yarışmayı Allah'ın rızasını kazanmanın temel şartı olarak öngörmüştür. Kültürel kaynaklarda da Hakan ve Hatun birlikte verilmiştir.

\subsection{Kadınların Kurduğu Vakıflar}

Kadınlar Osmanlı toplumunda aldığı terbiye ve eğitimin neticesi olsa gerek; her zaman hayır işleri ile anılmaktadır. Yaptığı birçok hayır işi bilinçli ve bir o kadar da ihtiyacı giderici özellikler göstermektedir. İncelenen döneme baktığımızda cami, çeşme, imaret, hastane vb. çoğu müessese kadınlar tarafindan kurulmuştur. Kurduğu vakıflar ve gerçekleştirdiği hayır işleri Osmanlı kadınının mülk sahibi olduğunu ve iktisadi anlamda erkeğe bağımlı olmadığının göstergesi olmuştur. Osmanlı kadını hakkında yapılan birçok çalışmada farklı sonuçların ortaya konması öyle anlaşılmaktadır ki; verileri yorumlama farklılığından kaynaklanmaktadır. Ayrıca dönemin özelliği gereği tek tip bir Osmanlı kadını modelinin olmayışı; zaman zaman tarlada üretken bir kadın, zaman zaman eşi savaşta bir aile reisi, zaman zaman vatan savunmasında civanmert asil kadın ve daha nice rolleri ile hayat bulan Osmanlı kadın modeli, değerlendirmelere çok farklı bakış açıları kazandırmakta, çok yönlü değerlendirmelere ihtiyaç duyulmaktadır. Kadının Osmanlı döneminde yaptığı örnek çalışmaları araştırdığımızda aşağıdaki verilere ulaşılmıştır. Kurulan büyük vakıflara 
baktığımızda: öncelikle saray kadınları ve Valide sultanlar karşımıza çıkmaktadır. Hayır işleri ile meşhur hanım sultanlar deyince; Mihrimah Sultan ${ }^{6}$, Hafsa Sultan, Mihrişah Valide Sultan ${ }^{7}$, Bezm-i Alem Valide Sultan, Hürrem Sultan ve daha niceleri akla gelmektedir.

Hayırsever ilk Osmanlı kadınlarından biri Nilüfer Hatun'dur. Nilüfer Hatun Bursa'da Bir tasavvuf tekkesi, bir cami ve bir köprü yaptırmıştır. Yine 2. Beyazıt'ın cariyesi Gülruh; Akhisar'da bir cami ve imaret kurmuş, ayrıca Aydın'da iki cami yaptırmışıı (Sınger, 2004: 104-105).

Saliha Hatun Şam'da bir vakıf kurmuş. Kurduğu vakfın amacı ise; "Haçlıların eline esir düşen Müslümanları kurtarmak ve evlerine dönene kadar tüm ihtiyaçların görülmesi” şeklindedir (Müftüoğlu, 2012: 95). Sultan Nakşidil Valide Sultan ise; yaptığı hayır işleri ile ünlü bir validedir. Fatih'te sebil, sıbyan mektebi, imaret, çeşme, Kasımpaşa'da namazgâh, çeşme, Sultanahmet'te Nakşi Kadın Çeşmesi, Sarıkadı köyünde Nakşıdil Valide sultan Çeşmesi yaptırmıştır. Şehrin mimari dokusuna katkıları azımsanmayacak kadar çoktur (Pazan, 2007: 123-124). Sultan 3. Murat'ın Kızı Ayşe Sultan eşi İbrahim Paşanın türbesinde Kur'an okumak, tespih çekmek, onun yerine kaza namazı kılmak ve hacca gitmek üzere görevliler tayin etmiş; ikinci vakfiyesinde ise; bir medrese yaptırılması, talebe ve müderrislerine ücret ödenmesi, muallim hane yaptırılması, muallim ve yardımcılarına ücret ve talebelere kıyafet verilmesini şart koşmuştur (Duran, 1990: 29-55). Sultan 4. Mehmet'in annesi Hatice Turhan Valide Sultan birçok hayırlı ve güzel işe imza atmış başka bir hanım olarak karşımıza çıkmaktadır. Vakfiyesinde; talebeler için kışın odun kömür masraflarını düşünerek 3000 akçe, yazın gezilere götürülmesi için; 3000 akçe, yazın sebilhaneye kar alınması için; 20.000 akçe, Ramazanda yoksullara dağıtılmak üzere; pirinç, soğan, odun alınmasını istemiş bunun için de 12.000 akçe vakfetmiştir. Hayır işlerinde durmak bilmeyen Hatice Sultan; Hacca gidecek adayları düşünerek yolda susuzluk çekmemeleri için hem yüklerini taşıyacak hem de su taşıyacak 65 adet deve kiralanmasını ve yeteri kadar su tedarik edilmesini buyurmuştur. Bununla da yetinmeyip camiler için; mum, kandil, zeytinyağı vs. için senede 3000 akçe, mübarek gecelerde kandil yakacak olan görevliler içinse senede 4000 akçe harcanmasını vakfetmiş̧ir (Duran, 1990: 61-87). Hac yolunda pek çok çeşmeler, sebiller ve köprüler yaptıran Sultan 4. Mehmed'in Baş Hasekisi, Haseki Gülnuş Valide Sultan; İstanbul'da Galata Yeni Camii ve Üsküdar'da bir camii yaptırmıştır. Ayrıca Mekke'de Darüşşifa, imaret, ambarlar, ekmek firını ve 21 adet köy vakfetmiş̧tir (Duran, 1990: 91-156). Sultan 2. Mustafa'nın kızı olan Safiye

${ }^{6}$ Hürrem Haseki Sultan'ın kızı Mihrimah Sultan da çok sayıda hayır eserleri yaptırmıştır. Edirnekapı'da bir cami, medrese, mektep, hamam ve çarşıdan oluşan bir külliye yaptırmış, bunun yanında Üsküdar iskele meydanında iki minareli cami, çifte kervansaray, mektep, hastane, imaret, medrese ve çeşmeden oluşan başka bir külliye daha yaptırmıştır. Ayrıca Arafat'tan Mekke'ye suyolları döşeterek havuzlar ve sarnıçlar yaptırmıştır.

${ }^{7}$ Mihrişah Valide Sultan'dır. "Eyüp'te İmaret, mektep, kütüphane, sebil ve türbeden oluşan bir külliye yaptırmış. Yine Halıcıoğlu Camii ile Levent ile Hasköy lağımcıları kışlalarında birer camii yaptırmıştır." Ayrıca İstanbul'un pek çok yerinde çeşme yaptırmıştır. Hayırsever Sultan halkın kullanımı için Eyüp bostan iskelesi yakınındaki kendi adını taşıyan imarethane yaptırmıştır. Ayrıca Eyüp Camii içinde bir de kütüphane tesis etmiştir (Alpgüvenç, 2010: 117-146). 
Sultan'a ait K.148 nolu vakfiye defterinde pek çok vakfiye mevcuttur. Vakfiyenin bir bölümünde; ...Sultan Mehmed Han Camiinde alanında usta bir bilgin tarafindan her pazartesi ve perşembe günü isteyenlere bilgiler öğretmesini, ders süresince ruhuna 3 ihlâs hediye etmelerini, ders veren bilgine günde 15 akçe verilmesini vakfetmiştir (Duran, 1990: 159-183).

O dönem kurulan ilginç bir vakıf Fatma Hanım Sultan vakfının şartları arasında farklı detaylar yer almaktadır. "Öğrencilere piknik yaptıran" Fatma Hanım; "biri kiraz vakti diğeri üzüm vaktinde olmak şartıyla yılda iki defa talebelerin pikniğe götürülmesini vakfetmiştir" (Müftüoğlu, 2012). Fatma Hanımın burada ortaya koyduğu şey bireyin toplumdaki rolünü aktifleştirerek, çok küçük ihtiyaçları dahi olsa belli oranlarda karşılanarak değerli olduklarını hissettirmek ve başarılarına destek sağlamaktır. Bu bağlamda günümüz Sosyal Hizmet Mesleğinin odak noktalarından birine vurgu yapmaktadır.

Hayırsever kadın sultanlardan bir diğeri de Sultan 3.Mustafa'nın kızı Şah Sultan'ın vakfiyesinde ise şu ifadelerine rastlanmaktadır:

“......Kış günlerinde çocuklar ve türbedarlar için vakfimın gelirinden Yılda yeteri kadar kömür alınsın. Senede bir defa adı geçen okulun öğrenci, ögretmen, görevlileri mesireye gidip yiyip içmek ve diğer giderleri için 100 kuruş harcansin...."

Ayşe Sîne-Perver Vâlide Sultan, İstanbul'da Atpazarı yakınlarında bir mektep, çeşme ve tatlı su vakfetmiştir. Bu hayratların akarı olarak da İstanbul'da 4 dükkan, 3 taş tekne, bostan, tarlalar, çiftlik , müştemilat........vs. şart koşmuştur. Yine yaptırdığı mektepte her ilkbaharda Peygamber Efendimiz adına bir mevlid-i şerif okunmasını vasiyet etmesi de manidardır (Duran, 1990: 391-427). Yine Zağnos Paşanın eşi Nefise Hanım'ın Vakfiyesi ise şöyledir: "Sındırgı kasabasındaki kâin cami-i şerifte imam olan kimseye her sene 150 dirhem ve hatip olan kimse için her sene 150 dirhem, çerağ yağları için 150 dirhem, tespih okuyanlara günlük 1 dirhem, Cuma geceleri Rasulullah (sav) nat ve mehdiye okuyan zata 15 dirhem tayin etti. Her y1l Rebiülevvel ayında pazartesi gecesi yapılacak ziyafet için 700 dirhem tayin etti. Bu gece mevlit okunacak, yemek dağıtılacak (Berki, 2006: 19-37).

Zikredilen bunca vakıf örneği ile Osmanlı kadınının kamusal hayatta zannedildiği gibi görünmez olmadıkları sonucunu çıkarmak mümkündür. $\mathrm{Bu}$ bağlamda toplumsal sorumluluk sahibi, bilinçli bireyler olduklarını da açıkça göstermektedir. Beyhan Sultan ${ }^{8}$, Nurbanu Valide Sultan', Saliha Sebkati Valide Sultan ${ }^{10}$, Rahime Perestû Valide Sultan ${ }^{11}$ ve daha niceleri.... Osmanlı kadınları toplumda ihtiyaç duyulan her konuda vakıflar kurarak tüm dünyaya örnek

\footnotetext{
${ }^{8}$ Sultan 3. Mustafa'nın diğer kızı Beyhan Sultan 1219 tarihli vakfiyesinde; Annesi Adilşah kadın için Mektep ve Edirnekapı'da cami yine aynı yerde su kuyusu, büyük-küçükbaş hayvanlar, değirmeni vakfetmiştir (Duran, 1990: 313-361).

9 2. Selimin eşi Nurbanu Valide Sultan, şu hayır işlerini yapmıştır: Üsküdar Toptaşı'nda Atik valide külliyesi, Üsküdar'da Yeşil Direkli Hamam, Divanyolu'nda Çifte Hamam (Pazan, 2007: 67-73).

${ }^{10}$ Osmanlı padişahı Sultan 2. Mustafa Han'ın Hanımı Saliha Sebkati Valide Sultan birçok çeşme yaptırmıştır; Azapkapı'da, Silivrikapı civarında Saliha valide sultan çeşmesi, defterdar civarında bir sebil yaptırmıştır. Bunun yanında Sıbyan Mektebi ve Hamam yaptırmıştır (Pazan, 2007: 105-208).

${ }^{11}$ Rahime Perestû Valide Sultan 'Silivrikapı' da Bâlâ Tekkesi'ne babasının ruhu için sebil, çeşme, muvakkithane, şadırvan ve müştemilat yaptırmıştır.“ (Pazan, 2007: 147-154).
} 
bir davranış sergilemişlerdir. Yukarıda ifade edilen vakıf örnekleri göstermektedir ki; gücü yettiğince her birey toplum ihtiyaçlarını gözeterek vakıflar kurmuştur. Osmanlı kadını yaptığı bu hayır işlerini gerçekleştirirken Kuran-1 Kerim'de yer alan; "Sevdiğiniz şeylerden (Allah yolunda) harcamadıkça, gerçek iyiliğe asla erișemezsiniz. Her ne harcarsanız Allah onu hakkıyla bilir." (Yazır, Ali İmran Suresi:92. Ayet meali) ayetini kendine rehber edinmiş, yaptığ 1 hayır işleri sınır tanımamıştır. Kendisinin sahip olduğu varlıklara diğer insanlarında sahip olmasını isteyerek, vakıf cenneti bir Türkiye vücut bulmuştur.

Kurulan vakıflar, yapılan bunca hayırlar sadece saray hanımları ile sınırlı kalmamış, Osmanlı kadınının gücü yettiği ölçüde bazen büyük bazen küçük gelirlerle Türkiye içinde olduğu kadar ülke sınırları dışında da vakıflarla hayırseverlikleri varlık bulmuş, topluma karşı olan sorumluluklarını yerine getirmişlerdir. Mütevazı araştırmamız neticesinde birçok vâkife ile karşılaştık. Kimi dini ritüellere saygı, kimi eğitime katkı, kimi yaşadığı mahallenin hayatını kolaylaştırmayı hedeflemiştir. Hedeflerine ulaşmada sahip oldukları imkânları sonuna kadar kullanarak; hayat kalitesini arttırmayı hedeflemişlerdir. Bu konuda derlenen diğer vakıflar şunlardır:

Samsun'da vakıf kuran Fatma Hanım gücü yettiği nispette sahip olduğu bir dükkânı vakfederek; her sene başta kendi ve akrabalarının ruhu için dört hatm-i şerif okunmasını, yine her sene bir mevlid-i şerif okunması istemiştir. ${ }^{12}$ Ayșe Hatun ise, eşini de unutmayarak vakfiyesinde ona da yer vermiş, ilim öğrenmenin bilincinde olarak; Yerkapı Mahallesi'ndeki iki mülkünü vakfetmiş. Vakfiyesinde:

"Kurduğu vakfin mütevelli ve nazırına günde birer dirhem ücret verilmesini ister. Her gün sevgili eşinin ve kendi ruhu için bir cüz Kur'ân-l Kerim okumasını talep eder. Ayrıca; her gün yatsı namazından sonra Yerkapı Mescidi'nde imam olan kişi tarafindan Muhammediye okunmasinı ister. Okuma ücreti olarak 60 dirhem ödenmesini öngörmektedir. Yats namazından sonra kitap okunmasinı talep etmesi hasebiyle de mescidin aydınlatılması ihtiyacını göz ardı etmemekte, mescidin kandiline mum konulması için 30 dirhem ayrılmasını, kandillerin yakılması için de mescidin kayyımına 10 dirhem verilmesini şart koşmaktadır." (Maydaer, 2009: 495508)

Yine Münire hanımın kurduğu vakfın şartları arasında da; Miraciye ${ }^{13}$ okuyup dinleyenlere şekerli süt ikram edilmesi, Şerife hanımın cemaate şeker dağıtılmasını istemesi dikkat çekici bir detaydır. Osmanlı kadınının aldığı eğitim ve terbiye yaptığı hayır işlerinde de ifade bulmaktadır. Münire Hanım 1919 tarihli vakfın şartları arasında şunlardan bahsetmektedir:

"Sahip olduğum bahçe kiraya verilsin her sene gelen gelirlerinden bahçenin vergisi ödendikten sonra, geriye ne kalırsa Recep ayının 27. Miraç Gecesi dergâhta harcanmak üzere oniki buçuk kıyye süt ve iki buçuk kıyye şeker alınarak miraciye okuyup dinleyenlere süt ve şeker karıştırllarak dağıtılsın...." (Zeyrek Soyer, 2007;VGMA, Dftr. No: 609, Sayfa sf. 36, sr. 48'den alıntı)

\footnotetext{
${ }^{12}$ Fatma Hatun Binti Salih Vakfi, SVGMA, VD No: 1751, sf. 30, sr. 17.

${ }^{13} \mathrm{~Hz}$. Muhammed'in göğe yükselişini konu alan edebi yapıtlardır.
} 
Şerife Hanım'ın vakfiye şartları ise şu şekildedir;“.....her yıl Şaban Ayının 15'inde Beraat gecesinde Lala Hüseyin Paşa Cami'inde mevlit okutulup, okuyanlara münasip ücret ve cemaate yetecek kadar şeker dağıtılması için yüz kuruş ayrılsın....."(Zeyrek Soyer, 2007;VGMA Dftr. No: 1751, , sayfa sf. 124, sr. 98. ....'den alıntı). Pazartesi günleri mülk süresinin okunmasını, hadis-i şerif nakletmesini ve sevabı cemîlinirûhuna hibe edilmesini isteyen; Şerife Ümmühâni Hâtun, Köyde yaptırdığ 1 musalla hayratının masraflarının karşılanması için vakıf kuran; Gaziantepli Hatice Hatun (Kavakl1, 2012: 313-326)."Köyde akmakta olan çeşmelerin tamir ve sağlamlaştırılmasını, haftada bir kere Yasin Suresi'ni okuyup, sevabını ruhuna hediye edilmesini arzu eden.” Ahmet Kızı Fatma Hanım vakıf kuran hayır sahibi hanımlardandır. (Zeyrek Soyer, 2007; Ahmet Kızı Fatma Hanım Vakfi vakfiyesi, sayfa VGMA, Dftr. No: 1751, sf. 132, sr. 106'dan alınt1).

Osmanlı döneminde ibadethanelerin en büyük ihtiyaçlarından biri aydınlanma sorunuydu (Kazıcı, 1985: 23-76). Osmanlı kadını yaşadığı toplumun hayat kalitesini koruma, arttırma, iyileştirme adına sosyal bir hizmet üstlenmiş vakfiyelerinde bu ihtiyaçları da unutmamış, şartları arasında yağ, kandil, mum teminini vurgulamıştır:

İmiş Hatun kurduğu vakıf ile bir evlek mülk bahçesini Allah rızası için vakfedip, şu şartları koşmuştur: "Bahçe mütevelli eliyle kiraya verilip, geliriyle aynı mahallede bulunan Yeşil Caminin ahşap minaresine astırdığı on iki adet kandile yeterli miktarda yăg alınacaktır." Yine Ayşe Hatun 1837 tarihinde, Kütahya şehrinde sahip olduğu kadayıfçı dükkânını şu şartlarla vakfetmiştir: Anılan dükkân kiraya verilerek kira bedeliyle şehirdeki Ulu Camii'nde Vakıf sahibinin asmış olduğu on adet kandile yetecek miktarda mübarek gecelerde yakılmak üzere yağ satın alınacak (Zeyrek Soyer, 2007; Cevdet Dadaş, Atilla Batur, İsmail Yücedağ, Osmanlı Arşiv Belgelerinde Kütahya Vakıfları II/3, sayfa 332'den alıntı). Fatma Hatun ise; sahip olduğu bir dükkân ve kahvehanesini vakfederek; senede sekiz hatm-i şerif okunması sevabının Peygamber Efendimiz başta olmak üzere Ashabı Güzin efendilerimize vefatından sonra vâkıfenin ruhuna hediye edilmesini ve Hançerli Camiinde bulunan kandillere her sene bir batman zeytinyağ 1 verilmesini şart koşmuştur. ${ }^{14}$

Salih Kızı Fatma ve Büyük Kızı Ayşe Hanım Vakfı: M. 16 Mart1827 tarihinde Kütahya'da iki kadın Salih kızı Fatma ve Sadriye-i Kebire kızı Ayşe binti Hacı Ebubekir şöyle konuşmuştur:

"Aynı şehirde Saadet Camii bitişiğinde Hezar Dinari Mescidi'nde mübarek gecelerde 10 tane kandil yakllsin ve yllda bir kere 10 üveylik bir yă̆ mumu satın alınarak mihrabın să̆ tarafina konulsun. Adı geçen bahçe kiraya verilip, ondan elde edilen gelir ile yeterli miktarda zeytinyağı satın alını mübarek geceler ve özellikle Ramazan ayında Takyeciler Camiinde 20 tane kandil yakllsin, yeterli miktarda meblăg, kayyım ücreti verilsin" (Zeyrek Soyer, 2007;Cevdet Dadaş, Atilla Batur, İsmail Yücedağ, Osmanlı Arşiv Belgelerinde Kütahya Vakıfları II/3, sayfa 258'den alıntı.)

Yukarıda bahsedilen vakıf çalışmaları ile toplumdaki önemli ihtiyaçlardan biri olan aydınlanma sorunu çözülmeye çalışılmıştır. Öyle anlaşılmaktadır ki

${ }^{14}$ Hacı Akça Mustafa zevcesi Fatma Hatun binti Hacı Bekir, SVGMA, VD No: 611, sf. 42, sr. 25. 
incelenen dönemde ibadethaneler büyük bir önem arz etmekteydi. Osmanlı kadını bu mekânlarda geçirilen zamanın uzun olduğunu, bu durumda aydınlanma ihtiyacının artacağının farkında olarak buna yönelik tedbirler almıştır.

Osmanlı döneminde sosyal hayatta su oldukça öneme haizdi. Mahalle çeşmeleri çok kullanılmakta ve büyük ihtiyaçları karşılamaktaydı. Sık kullanılması nedeniyle de sık sık tamire ihtiyaç duyulmaktaydı.(Kazıc1, 1985: 28-76). Sosyal hayatın bizzat içinde yerini alan Osmanlı kadını yaşadıkları toplumun ihtiyaçlarını da en iyi bilen kişiydi. Bu büyük ihtiyacın karşılanması içinde yine birçok vakıflar kurulmuş, vakfiye şartları arasında bu konuya yer verilmiştir. Ayrıca dini ritüellere saygılı Osmanlı kadını Peygamber(sav) tavsiyesi olarak gördüğü çeşme vakfetme hayrını da göz ardı etmemiştir. ${ }^{15}$ Osman Kızı Ummühani Hatun 9 Mayıs 1835 'te, Kütahya'da kurduğu vakfında vakfettiği dükkânların kiraya verilerek çamaşırhane ve çeşmesinin tamir edilmesini istemiştir. Yine hayırsever Halime Hanım kurduğu vakıf ile çok isabetli ve bilinçli bir hayır işlemiş, gelirini "eşi merhum Hacı Ebubekir Efendi'nin yaptırdığı çamaşırhane ile çamaşırhaneye akan suyollarının tamirine" harcanmasını istemiştir. Dönemin en çok ihtiyaç duyulan bir eksiğini kapatma adına çalışmalarda bulunmuştur. Emetullah Hatun'da bu konudaki ihtiyacı fark etmiş olacak ki kurduğu vakıfta $\mathrm{O}$ da bu konuyla ilgilenmek istemiştir. Vakıf gelirinden senelik 100 kuruşu mezkûr çeşmelerin tamirine, muhtaç olan suyollarına harcanmasını şart koşmuştur. (Zeyrek Soyer, 2007; Mehmet Kızı Emetullah Vakfı, VGMA, Dftr. No: 605, s.7). Yine Samsun Vezirköprülü Ayşe Hanım $^{16}$ vakfiyesinde; Bafra ve Geder kasabasında bina olunan çeşmeler ve suyollarının hizmetleri için günlük yirmi akçe verilmesini, her ramazanda adı geçen camiye yanacak kandil için her sene beş kuruş verilmesini şart koşmuştur. Nazilli'de Fatma Ana, Sandıklı'da Fatma Hanım $^{17}$ ve daha niceleri bu konuda birçok vakıflar kurarak sosyal bir hizmet gerçekleştirmişlerdir. Öyle anlaşılmaktadır ki, sosyal hayattaki ihtiyaçlar dikkate alınmak yanında yapılan hayır işlerinin devamında karşılaşılabilecek ihtiyaçlar düşünülerek tamir masrafları da hesaba katılarak yapılan hayır işlerinin sürekliliğini sağlanmıştır. Böylelikle kendilerinden sonra da yaptıkları vakıf hizmetlerinin devamını sağlamışlardır.

Yaşadığı toplumdaki sorunlara duyarsız kalmayan Osmanlı kadını; sorunların çözümü konusunda farklı fikirler üretmiş, toplumun refahına katkı sağlamıştır. Eğitim-öğretime büyük önem vermiş, eksikliklerin giderilmesi için çaba göstermişlerdir. Tokat'lı Âyişe Hatun Bint Cin Ali bir vakıf kurarak gelirinden 300 kuruşu medreseye vakfetmiştir. Yeni daire medresesindeki talebeye verilmesini kalanı ise muallimine verilmesini istemiştir (Sağırlı, 2005: 297-298).

\footnotetext{
15 “İçme suyu Medine'de çok yüksek fiyata satılmaktaydı. Pek çok kişi bunu karşılayamıyordu. Peygamber; inananlara sağlıklı içme suyu ve dua etmeden önce günlük ibadetleri yerine getirme için bir çeşme almayı ve herkesin kullanması için vakfa çevirmeye davet etti. Peygamberin zamanından beri bu adet devam etmiştir." Albılal, Rawaa N.(2013)."Vakıf Hayırseverlik Sistemi-Bizi Bağlayan Değer", Dünya Vakıflar Konferansı 23-24 Eylül 2013.(ss.185-187)İstanbul: T.C. Başbakanlık Vakıflar Genel Müdürlügü.

${ }^{16}$ Köprülü Zade Mustafa Paşaannesi Ayşe Hanım Binti Yusuf, SVGMA, VD No: 604, sf. 208, sr. 303.

17 Nazilli Hamzalı köyü/Fatma Ana Vakfi/Köyde kuyu yaptırmış, ip-kova alınmasını, tamir masraflarının karşılanmasını şart koşmuştur. Sandıklı Ali Ağa kızı Fatma Hanım Vakfı/ Üç kumalı çeşme ve yolların tamirini üstlenmiştir (Vakıflar Umum Müdürlüğ̈̈, 194: 17-20).

* Fahri Kızı Ümmühani Hatun Vakfi/1813/Kütahya (Zeyrek Soyer, 2007).
} 
Fahri Kızı Ümmühani Hatun'da vakfiyesinde buna yer vermiş sahip olduğu dükkânını Allah rızası için vakfedip şöyle şart etmiştir: "Adı geçen dükkân kiraya verilerek, Kara Hacı Mehmet Ağa'nın yaptırdı̆̆ı medresede bulunan iki kapı hücrelerin her birine senelik 120'şer akçe para verilecektir".(Zeyrek Soyer, 2007;VGMA, Dftr. No: 1751, sayfa 140'dan alıntı). Bir diğer vâkıfe ise Hacı Mehmet Kızı Şerife Hatun1808 tarihli vakfiyesinde; "1 kapı ev bahçesini vakfederek, bahçeyi kiraya verip gelirinden Sultan Yıldırım Bayezit Han Camii medresesinde din ilimleri okutacak müderris İsmail Efendi'ye verilmesini şart etmiştir." (Zeyrek Soyer, 2007; Osmanlı Arşiv Belgelerinde Kütahya Vakıfları II/3, sayfa 274' den alınt1).

Yardımseverlik ve dayanışmanın sembolü vakıflar birçok alanda Osmanlı toplumunda görülmekteydi. Toplumun ihtiyaçları göz önüne alınarak sosyal hizmet alanında birçok vakıflar kurulmuştur. Bu bağlamda Osmanlı kadınının toplumda silik bir kişilik sergilediği ifadelerinin aksine hemen her alanda karşımıza çıkmaktadır. Özellikle kurulan vakıflarda mütevelli olarak kadınların tercih edilmesi onlara verilen değerin bir kez daha altını çizmektedir. Birkaç örneği şu şekilde görmekteyiz:

Hac1 Ebubekir'in Hanımı Mehmet kızı Şerife Hatun vakfiyesinde; Halilürrahmi Efendi Dergâhı'nda halvete giren Halvetî dervişlerinin şerbet masraflarının karşılanması, yaptırdığı üç adet çeşmenin onarımının yapılmasını şart koşmuş. "Vakfıma kızım Fatma mütevelli olacak" ifadeleri ile kadınlara verilen değeri göstermektedir. Ayşe Hatun 1853 tarihli vakfiyesinin sonunda; "Hayatta olduğum sürece vakfın mütevellisi ben olacağım ve evimde oturacağım. Vefatımdan sonra kızım Selim kızı Habibe mütevelli olacak ve kocası olan damadım İbrahim'le birlikte evde oturacaklar."*'Yine Ayșe binti İsmail, sahip olduğu bir çiftliğini vakfetmiş ve Fatma Hatun isimli kişiyi de mütevelli tayin etmiştir. Elde edilen gelirin günlük 1 akçesi Yenice Mahallesi'nde bulunan Saray Köprüsü'nün tamirine harcanacak, kendisi vefat ederse Mütevelli Fatma Hatun'a günlük lakçe köprünün tamirine, geri kalan gelir ile de her yıl vâkıfın ruhu için 1 hatm-i şerif tilavet etmesini şart koşmuştur. (Özlü, 2006: 193-208). Araştırmamız sırasında; Hacı Mustafa Kızı Havva Hatun, Ayşe Hanım ve Ömer Kızı Sarımsakçıŏlu Hacı Hasan Karısı Şerife Hatun'un da kurdukları vakfın mütevellisi olarak kızlarını atadıkları görülmektedir (Zeyrek Soyer, 2007; VGMA, Dftr. No: 609, sayfa 27, 138, 289'dan alınt1). Tüm bu eserler Osmanlı toplumunda merhamet ve yardım duygularının gelişmiş olduğunu göstermektedir. Burada toplumcu bir düşünceden bahsedilebilmekteyiz. Osmanlı kadını sadece çeşitli eserler, hayır kurumları yaptırmakla kalmamış bunların devamı için de vakfiyelerinde şartlara yer vermişlerdir.

Osmanlı döneminde sınırları oldukça geniş bir coğrafyaya yayılmıştı. Osmanlı hoşgörüsü ile birçok ülkede örnek alınarak; Osmanlı ahlakı, gelenek ve adetleri fethedilen yerlerde de etkilerini göstermektedir. Öyle anlaşılmaktadır ki; Vakıf geleneğinin diğer uluslarca da kabul görmesinde Osmanlı dönemindeki bu

\footnotetext{
* Mehmet Kızı Ayşe Hatun Vakfi/1853/Kütahya. Mehmet Kızı Ayşe Hatun sahip olduğu bir kapı evini Allah rızası için şu şartlarla vakfetmiş: "Bahsedilen evde vakfa mütevelli olan kimseler oturacak ve yıllık beşer kuruş şehrin fakirlerine gönderecekler. VGMA, Dftr. No: 1751, sf. 82, sr. 57.
} 
örneklerin olumlu katkıları önemli bir etken olmuştur. Mütevazı araştırmamız sırasında Bosna Hersek'te karşımıza çıkan vakıflar takdire şayandır. Saray Bosna kentinde vefat etmiş Hüsrev Bey'in Eşi Şahdîdâr Hanım hem eğitim hem de dini amaçla yaptığı hayır işi ile birçok alanda topluma katkı sağlamıştır. Şahdîdâr Hanım 115.000 akçe vakfederek bir mescit ve mektep yapılmasını istemiştir. Yine aynı vakfiyede İmam, müezzin ve muallim maaşı verilmesini vasiyet ederek yaptığı hayrın yanında görevlilere verilmek üzere vasiyet etiği ücret ile de ekonomik anlamda bir yarar sağlamıştır. Yine 1528-1540 yılları arasında Saraybosna'nın Mejtasm mahallesinde Dudi Bula (veya Tuti Bula) adlı bir kadın da mescit yapılmasını istemiştir. Nefise ve Hanife adında iki kadının ise toplam 5.000 akçe vakfettikleri belgelerde yer almaktadır. Fatma adında başka bir kadının 3.600 akçe ile bağış yaptığı belgelenmiştir. Voyvoda Sinan'ın kızı Hatice Hatun bir vakıf kurmuş, cami ve iki okul inşa ettirmiştir. Saray Bosna'da Hersek' te birkaç dönem sancakbeyliği yapmış olan Sinan Beyin karısı, Sokullu Mehmet Paşanın da kız kardeşi malından 80.000 akçe bağışlamış, vakıf mütevellisi ve muhasebecisinin maaşlarının ödenmesini, mescit ya da ihtiyaca göre başka bir hayır binasının inşa edilmesini vakfetmiştir. Fakir medrese hocalarını desteklemek için onlara bir fon ayıran ve bu okulun öğrencilerine battaniye ve odun alınarak 1sınmalarının sağlanmasını isteyen Mostarlı Ayşe Hanım, yine vakfının fonlarının bir kısmını eğitim amaçlı kullanılmasını özelliklede kadınların eğitimine ayrılmasını isteyen Fatime Aşide Hanım vakfiyesinde; "be-her sene receb ve şa'bân ve ramazân aylarında haftada birer defa Yahya Paşa Câmi'-i şerîfdenisâ' tâifesineva'zü nasihat edüp vâiz efendiye fazla-1 mezkûredenemsâlimisillüikrâm edilecek..."ifadeleri yer almaktadır (ButurovıḈ ve Shıck, 2009: 110-136).

Yukarıda ifade edildiği üzere; kurulan vakıflarla makro düzeyde bir hizmet sunan Osmanlı; sınırları aşan hayır çalışmaları ile dünya sahnesinde de kıymetli bir yer edinmiştir.

Kıbrıs'ta da kadınların kurduğu vakıflar karşımıza çıkmaktadır. Lefkoşa'da yaşayan Gülsüm Bint-i Derviş bir evini vakfederek, Peristerona Köyü Camisi imamına verilmesini bunun karşılığında her sabah Yasin-i şerif okuyup sevabını vakfın kurucusunun ruhuna hediye etmelerini istemiştir. Hatice Hatun ise; Ayasofya Camiinde kuşluk vaktinde kendi ruhu için Kur'an-1 Kerim'den bir “cüz- $i$ şerif" okunması ve bu görevi yapacak kişiye günlük iki akçe verilmesi şartıyla dört bin akçe vakfetmiş̧ir. Yine Cemile bint-i Abdülkadir Hatun bir vakıf kurarak; her ay ulemadan bir kişinin Kur'an-1 Kerim'den bir cüz-i şerif okumasını ve vakfın kurucusunun ruhuna hediye etmesini, bunun karşıllı̆ıında bir sülüs kuruş ödenmesini şart koşmuştur (Demiryürek, 2011: 941-960).

Osmanlı'da ülke sınırlarını aşan diğer vakıflar dini ritüeller dikkate alınarak düşünülmüss, Osmanlı kadınlarının inancına olan bağlılığını yansıtan kutsal topraklarda hayat bulmuştur. Bu alanda kurulan vakıflara baktığımızda şu vakıflar karşımıza çıkmaktadır: Hacı Mehmet Kızı Şerife Hanım, Soytarı Yusuf Kızı Emetullah Hanım, Mustafa Kızı Havva Hatun, Hacı Hasan Ağa'nın Eşi Emine Hatun kurdukları vakıflar ile Mekke ve Medine'deki fakirlere mülk ve çeşitli miktarda para vakfetmişlerdir.

Hasibe Hanım ise fakirler dışında oradaki askerleri de düşünmüş, oralarda gerek olabilecek tamir işlerine de vakfiyesinde yer vermiştir. 
"Sahip olduğu bir kapı ev ile Meydan Mahallesi'ndeki meyve ăgaçlı ve meyve ăgaçsız tahminen iki buçuk dönüm bahçeden her birini vakfederek çeşitli hayır işleri gerçekleştirdikten sonra $O$ da gelirin bir kısmını Medine-i Münevvere'de Harem-i şerif civarında bulunan vekâletlerin tamirine harcansın ve orada oturan fakirlere muhtaç olan askerlerden münasip olanlarına mütevelli eliyle dă̆ıtılmasını şart koşmuştur."(Zeyrek Soyer, 2007; VGMA, Dftr. No: 603, sayfa 15'den alıntı).

Zeki Osmanlı hanımları Mekke ve Medine'deki muallimleri de unutmamıştır. Vâkıfe Zeynep Hatun* vakfının gelirlerini Medine'deki Alaca Mescidindeki muallim ve talebelere vakfederek, her sene beraat kandilinde mum yakılması ve kendi ailesinin ruhu için her cuma kuran okumasını şart koşmuştur (Sağırlı, 2005: 297-299). Hüseyin Kızı Refia Hanım ise 1796 tarihli vakfiyesinde"...yıllık 350 akçe Medine'de Ravza-i Mutahhara hizmetçilerine verilmesini" şart koşmuştur (Zeyrek Soyer, 2007; Osmanlı Arşiv Belgelerinde Kütahya Vakıfları II/3, sayfa 247'den alıntı). Daha birçok hayırsever kadını kutsal topraklardaki vakıfları ile sayabiliriz: Hacı Rabia Hanım ${ }^{18}$, Hacı Fatma Kadın ${ }^{19}$, Fâtma Hanım²0, Hâkime Hatun ${ }^{21}$, Ayșe Sultan'22 bunlardan sadece bir kaçıdır.

\subsection{Erkeklerin Kadın Hizmetlerine Yönelik Kurduğu Vakıflar}

Osmanlı toplumunda kadınlara verilen değer kendi kurdukları ve kendileri için kurulan vakıflarla bir kez daha ifade bulmaktadır. Birçok erkek Osmanlı kadınının ihtiyaçlarını düşünerek toplumda hayatlarını rahat bir şekilde ikame edebilmesi için gayret göstermiştir. Kendi aileleri dışında toplumdaki diğer kadınlara yönelik vakıflar da kurmuşlardır. Osmanlı döneminde Saray erkekleri tarafından kurulan vakıf külliyeler toplumsal bütünleşmeyi destekleyici bir nevi sosyal merkezler hükmündedir. Külliyeler etrafında oluşturulan mahallelerle ideal bir yaşam ortamı oluşturulmakta, toplum refahı öne çıkarılır. Böylelikle vakıf külliyeler, Halim Baki Kunter'in ifadesi ile "Sosyal Katalizör" rolü oynamıştır (Kunter, 1939: 108). Osmanlı kadını gerek eş, gerek kardeş, gerekse evlat olarak her dönem Osmanlı erkeği tarafindan saygı görmüş, onlar adına yüzlerce hayır kurumu ve vakıflar hayat bulmuştur. Özellikle saray erkekleri yaptırdıkları hayır

\footnotetext{
* Zeynep Hatun Bint Abdullah'ın Bahçe vakfi/1796/Tokat.(Sağırlı, 2005: 297-299).

${ }^{18} 1878$ tarihli vakfiyede; Hacı Rabia Hanım bir kapı mülk evi Her sene Mekke fakirlerine onar kuruş gönderme şartıyla vakfetmiştir.(Zeyrek Soyer, 2007; Osmanlı Arşiv Belgelerinde Kütahya Vakıfları II/3, sayfa 236'dan alınt1).

191865 tarihinde bir vakıf kurarak şunları ifade etmiştir: "iki buçuk evlek bahçesini çeşitli hayır işleri için vakfettikten sonra aynı gelirden yıllık on kuruş Mekke fakirlerine gönderilecektir" (Zeyrek Soyer, 2007; VGMA, Dftr. No: 1751, sayfa 132'den alınt1).

${ }^{20}$ Fâtma binti Yusuf Vakfi Vakfiyesi: Medine'de Takyeciler Camiinde her sene beraat kandilinde balmumu yakılması yine vakıf gelirlerinden bir miktarını zikredilen camii imamına gönderilmesini şart koşmuştur. (Sağırlı ve Açıkel, 2005: 297-299).

${ }^{21}$ Hacı Salih Ağa Kızı Hâkime Hatun Vakfi: 20 Ağustos 1805 tarihli vakfiyesinde her sene dört adet İstanbul altını Medine'de oturan fakirlere gönderilerek sadaka edilmesini şart koşmuştur. (Zeyrek Soyer, 2007; , VGMA, Dftr. No: 1751, sayfa 74'den alınt1).

22 III. Murad'ın kızı Ayşe Sultan tüm mal varlığını muhtaçlara bırakmış. Yaptığı birçok hayır işi yanında özellikle Mekke, Medine ve Kudüs fakirlerine ve ilk önce kadınlar olmak kaydıyla esir düşmüş Müslümanların fidyelerinin ödenmesini şart koşmuştur (Eraslan, 2011: 124-138).
} 
müesseseleri ile eşleri ve validelerini her zaman özel bir yere koymuşlardır. Sipahi Çataltepe İslam-Türk medeniyetinde Vakıflar adlı eserinde; Fatih sultan Mehmet'in darüşşifasında kadınlar ve azınlıklar için bir hastane olduğunu ifade etmektedir. (Çataltepe, 1991: 36-43). Daha birçok eser Osmanlı tarihinde yerini almıştır. III. Selim'in Edirne'deki “Merkez-Selimiye Külliyesi”, Sultan I. Ahmet'in ise İstanbul Eminönü'ndeki "Sultanahmet Külliyesi” bunların sadece birkaç örneğidir.

Mimar Sinan vakfiyesindeki bir bölümde şunlar yer almaktadır: Merhum eşi Mihri Hatun için iki kişiye günde bir cüz okumalarını sevabını merhumun ruhuna bağışlamaları şartı ile günde birer akçe maaş verilmesini şart koşmuştur. Yine kızları Ümmihan, Neslihan ve şehit oğlu merhum Mehmet Bey'in Fahri adlı kızına günde on bir akçe maaş verilmesini istemiştir. Bu arada Kayseri'den getirtip Müslüman eylediği kardeşi oğlu kızlarının Raziye ve Kerime'ye hayatta oldukları müddetçe günde beşer akçe verilmesini şart koşmuştur. Hayatta oldukları sürece vâkıfı hayır dua ile anmalarını istemiştir (Ateş, 1990: 82-87). Mimar Sinan'ın vakfiyesindeki bu bölümde ailesindeki hanımlara gösterdiği ihtimam dikkat çekicidir. Mikro düzeyde bir sosyal hizmet sergilemekte olup; toplumdaki rollerini ifa etmede aile üyelerine destek sağlamaktadır.

Halk arasında da gücü yettiğince kadınlara yönelik vakıflar kuran bireyler görülmektedir. Tokat Müftüsü Veliyyüddin Mehmed Efendi kurduğu vakfın vakfiyesinde: "Karamani Mescidinde hanımı ve annesinin ruhu için hadisi şerif talim ve tilavet edilmesini, her sene beraat kandilinde mum yakılmasını şart koşmuştur.” Elhâc Mehmed b. Hamza Beşe kurduğu vakıfla medeniyetler üstü bir davranışa imza atarak, iddia edilenlerin aksine kızları; Fatıma, Hatice ve Emine'ye bir han ve bir dükkân bırakarak gelirlerini kızlarına hatta onların vefatı durumunda özellikle kız torunlarına bırakmıştır. Bu bağlamda Osmanlı döneminde kadına verilen değere tekrar vurgu yapmak önemli bir noktadır. Sünnetçi-oğlu Hacı Abdullah Efendi Tokat'ta bir vakıf kurarak; bağ, bahçe ve dükkânlarını kayınvalidesine, ölümü halinde eşi HüsnâŞâh'a bırakmıştır. Vakfın fazla gelirinin Medine-i Münevvere de Ravza-i Mutahharanın şeyhine ve Medine fukarasına vakfetmiş̧ir. Bunların dışında; baldızına, validesine ve köleleri için de çeşitli şartlar yer almaktadır. (Sağırlı ve Açıkel, 2005: 249-282). Bu bağlamda Osmanlı döneminde kurulan vakıfların vakfiyelerinden açıkça anlaşılacağı üzere; bu dönemde dini ritüeller büyük bir önem arz etmektedir. Kurulan her vakfın şartnamesinde manevi istekler dikkat çekicidir. Burada toplumun kültür ve geleneklerini bağlı bir yaşam sürdügüü düşüncesi desteklenmektedir. Kültürün taşıyıcılık işlevi ile birçok gelenek görenek adet ve inanışların kuşaktan kuşağa aktarıldığı düşünülmektedir. Dolayısıyla vakıfların kültür aktarımında "Kültürel bir Sosyal Hizmet işlevi” gördüğü ortadadır. Bu hizmetlerin gerçekleşmesinde kadının rolü de azımsanmayacak derecede önemlidir.

Osmanlı döneminde bazı aileler çocuklarına kız-erkek eşit davranarak benzer imkânlar sağlamaya çalışmıştır. Gerek sosyal imkânlarla gerekse vefat ettikten sonra miras taksimlerinde buna ayrı bir önem göstermiştir. Söz gelimi, Ferişte-zade Müderris Hamza Efendi H.1044 tarihinde, Manisa'da tesis ettiği vakfının gelir fazlasını, erkek ve kız evlatlarına eşit bir şekilde şart koşmuştur. Bunun yanında bütün mirasını vakıf yoluyla kız evladına bırakan vakıf kurucularına da rastlamak mümkündür. Yine bazı vakıf kurucularının, tesis ettikleri vakıflar yoluyla, kadınların iffetlerini korumalarını sağlamayı amaçladıkları 
görülmektedir. Karaçelebizade Mehmed Efendinin vakfiyesinde: "fisk u ficûrdanâri olan utekalarının dul kadınlarına senevî 200 akçe tahsis edile." ifadeleri bunun bir örneği olarak görülmektedir. Şunu da burada vurgulamakta fayda görmekteyim. Yaptığımız araştırmada gördük ki; Gedik Ahmet Paşa Vakfının nazırının kızı yönetici olarak vakıf idaresinde bulunarak, bu bağlamda Osmanlı toplumunda kadının yönetici olabildiği yegâne hizmet alanının vakıflar olduğunu bize göstermiştir (Yüksel, 1999: 45-56).

\subsection{Kadınlara Yönelik Vakıf Hizmetleri}

Osmanlı toplumunda pek çok hanım; duâhan, duâgûyan, ihlâshân gibi isimlerle vakıflardan yardım almaktaydı. Vakıf kurucularının ruhlarına Kur'an okumaları için cüzhân, duâhân, ihlâshân tayin etmeleri yaygın bir gelenek olarak karşımıza çıkmaktadır (Yüksel, 1999: 45-56). Osmanlı'da, arşiv belgelerine göre, çeşitli sebeplerle maaşlar alan veya yardım gören, reâyâdan hanımlar da mevcuttu: Üçüz çocuk sahibi olanlara çocuk başına beș akçe toplam on beș akçe (günlük) maaş bağlanması (gümrüklerden) kânundu. Vakıflardan taâmiyye (yemeklik) alan hanımlar da vardı. Depremde evi yıkılanlara tamir edilmesi için gereken meblağ hazîneden ödenerek ev tamir ettirilirdi. Yine ihtidâ eden (hidâyete eren) hanımlara "kisve bahâ" verilmesi; hasta, ihtiyar ve muhtaç kadınlara, düşman tarafından yaralanan hanımlara maaş bağlanması görülen uygulamalar arasındadır. Yine Peygamber Efendimizin torunları Hz. Hasan ve Hz. Hüseyin'in soyundan gelen kişilere de maaşlar bağlanmıştır. Osmanlı imkânı ölçüsünde halkının fakir ve fukara olanlarına destek sağlıyordu (Baş, 2006). Toplumda her bireyin ihtiyaçları bu kadar detaylı olarak düşünülüp şartlar koyan bir Osmanlı toplumunda kadınlar nasıl değersiz bir met'a olarak görülebilir?

Kemal Savc1, "Cumhuriyet'in 50. Y1lında Türk Kadını" adlı eserinde; Osmanlı kadınının toplum hayatında sosyal yönü ile her zaman yer aldığını, vakıflar sayesinde güçlü bir sosyal yönlerinin olduğunu ifade etmiş; analık ve eş vasfi yanında erkeklerden geri kalmayacak ölçüde toplum yararına hayır işleri ile meşgul olmuş, birçok eserler ortaya koyarak, Osmanlı kadınının sosyal yönüne vurgu yapmış, kurdukları vakıfları bu anlamda örnek göstermiştir (Savc1, 1973: 4049).

Bireylerin yaşadıkları yerleşim yerleri onların yaşam şekillerine yön vermektedir. Dolayısıyla Kadınların toplumdaki varlıkları kır ve kent yaşamlarına göre farklılık göstermektedir. Buda Osmanlı toplumunda kadının durumunu tespit etmede çeşitli problemlere sebep olmuştur. Gerçek bilgilere ulaşmada farklı bakış açıları ve yorumların varlığı da başka bir engel olarak karşımıza çıkmaktadır. Kadınlara yönelik kurulan birçok vakıf örneği dışında özellikle kadınlara yönelik hizmetlere vurgu yapan hayırseverlerle de karşlaşmaktayız. Bu hizmetleri incelerken benzer özellikler gösteren vakıfları birlikte inceleyerek yapılan çalışmaları anlamlandırmayı hedefledik.

Tarihe baktığımızda Vakıfların toplumdaki en büyük rollerinden birinin ihtiyaç sahibi kişilere gıda temininde bulunmak olduğunu görüyoruz. Çeşitli sebeplerden dolayı müşkül duruma düşmüş bireylere yardım için birçok hayırseverler hazırladıkları vakfiyelerde bu isteklerini özel şartlarla belirtmiştir. 16. 
yüzyılın ikinci yarısında yaşamış olan Vâkıfe Zeyni Hatun, ${ }^{*}$ bu hayırseverlerden biridir. Yardıma muhtaç çeşitli gruplara düzenli bir ödenek ayırıp; bu ödeneğin yedirip içirme ve üst baş alımı işlerine harcanmasını vasiyet etmiştir. Yemek pişirilerek fakirlere dağıtılmasını, yiyecek alınıp bunların adı geçen okulda öğrenim gören öğrencilere, kadın ve erkek azatlılarından yoksul olanlara verilmesini şart etmiştir. Burada Zeyni Hatun'un özellikle öğrenim gören öğrencilere de yer vermesi manidardır. Bir diğer vakfımız Zekiye Hanım Bint-i Mehmed Vakfı'dır." Zekiye Hanım 5 Temmuz 1905 tarihli vakfiyesinde: Samsun merkezde kasaplar arastasında bulunan bir dükkân vakfedip cuma ve pazartesi günlerinde Yasin okutulması; yazın kadınlara ve çocuklara soğuk su dağıtılmasını istemiştir (Okudan, 2011: 267-277). Yazın kavurucu sıcağından en çok kadın ve çocukların etkileneceği düşünülerek, vakfiyesinde böylesi ince bir detaya yer veren Zekiye Hanım, kurduğu bu vakıfla hayır yarışında yerini almıştır. Haca-i Sultaninin* de Zekiye Hanım gibi kurduğu vakfın vakfiyesinde; Soğuk su dağıtılacak, ibaresine rastlanmaktadır (Müftüoğlu, 2012:69).

Fatma Hatun Binti Süleyman Efendi Vakfı 1720 M. Tarihinde İstanbul'da kurulmuş. Vakfiyesinde şu ifadeler yer almaktadır: “....Mekke ve Medine fakirlerinden ikişer kişiye her sene 5'er altından toplam 20 altın gönderile; ihtiyaç olan bölgelerde on adet su kuyusu açtırıla ve ahalisinden borçlu olanlarına yardım edile..." Topkapı sarayında Arpa emini olan Süleyman Efendinin kızı Fatma Hatun ülkemizde yaptığı birçok hayır dışında Haremeyn'de de böyle bir vakıf kurarak cömertliği kilometreler ötesine taşınmıştır. Bu vakıf sayesinde inancı gereği saygı duyduğu kutsal yerlerin halkının ve ziyaretçilerinin susuzluk çekmemesi için gayret göstermiş̧tir (Müftüoğlu, 2012). Kırım Hanı Mengli Giray kızı, Yavuz Selim Han'ın zevcesi Hafsa Hatun İstanbul'da Hicri 929 y1lında bir imaret kurulmasını vakfetmiştir. Vakfiyesinde; İmarethanede her gün Allah rizası için yemek pişirilmesini, sabah ve ikindiden sonra olmak üzere iki defa yemek pişirilmesini, pişirilen yemekten fakirlere, medrese talebelerine, ister fakir ister zengin olsun tüm misafirlere yemek ikram edilmesini özellikle muhtaç durumda olanların karınlarının doyurulmasına engel olunmamasını vakfetmiştir (Alpgüvenç, 2010: 60). Ayrıca Urla'da bir mescit ve Kırkağaç’ta bir çeşme yaptırmıştır.

Yine "Fakirlere gıda yardımı yapmak, bayramlık eşya dağıtmak, kurban bayramında kurban kesip et ve kurbanlık dağıtmak" amaciyla kurulan Zeliha Hanım Binti Abdullah Vakfı Hicri 1273 yılında İstanbul'da kurulmuştur (Müftüoğlu, 2012). Gaziantep' de kurulan Rahime Hatun İbneti İbrahim Ağa İbn Mehmed Bey vakfını kuran Rahime Hatun; Erik bahçesini vakfederek gelirinden arife gününde koyun satın alınıp etinin fakirlere dağıtılmasını, her ramazanda hatim okuyup sevabını Vâkıfenin ruhuna bağışlayan kişiye de belli bir miktar ücret ödenmesini şart koşmuştur (Kavakl1, 2012:313-326).

İhtiyaç sahibi kişilere gıda temini için kurulan vakıflarda erkeklerin de gayretlerini görüyoruz. Fatih Sultan Mehmed Han 1470 M. tarihli vakfiyesinde; "Imaretten, dul kalmış Saliha hanımlar için yemek verilip, namus ve iffetlerinin muhafaza edilmesini" istemiş. Ayrıca İmarete gelen misafirler, görevliler

* Zeyni Hatun binti Kemal Ağa/1588/İstanbul.

*Zekiye Hanım bint-i Mehmed Vakfi / 1905/Samsun.

* Hayırda yarışan Hoca-i Sultani Vakfi/1571/İzmir. 
tarafindan güler yüzle karşılanıp, misafir olarak kalmak isterlerse, üç günden çok olmamak üzere misafir edilip, yeme-içme ihtiyaçlarının karşılanmasını buyurmuştur (http://www.vgm.gov.tr/, e.t: 12.11.2012). Ayrıca Sipahi Çataltepe, Vakıflar adlı kitabında Fatih Sultan Mehmet'in Kadınlar ve Azınlıklar için bir hastane yaptırdığını ifade etmiştir (Çataltepe, 1991:36-41). Amasya'da kurulan 2. Sultan Beyazit Vakfi vakfiyesinde; Beyazid Camii civarında bir imaret-i şerife bina edilmesi “.....Akşam sabah orada yemek pişirilip oraya gelen yolcular, yoksullar, dullar, yetimler ve diğer müminler buradan yemek yerler. Hiçbir kimse mahrum bırakılmaz...." ifadeleri yer almaktadır (Müftüoğlu, 2012).

Osmanlı toplumunda özel günlerin ayrı bir yeri vardı. Hayır, işlerine gönül vermiş kişiler bu özel günleri unutmamış, özellikle o günlere has hayırlar yapılmasını vakfetmişlerdir. Onlardan biri de Abide Hatun. Bursa'da tesis ettiğ i vakfından her Cuma Alâeddin Camii'nde zikredilen dervişlere pilav, zerde, yahni ve şerbet ikram edilmesini, aşure dağıtılmasını istemiştir.1605 yılında Bursa'da çeşitli menkul ve gayrimenkuller vakfederek adeta bir sosyal yardımlaşma vakfı kuran Abide Hatun, tanınmış ve ileri gelen bir aileye mensuptu. Vakfiyesinde; dul, yetim ve fakirler için çeşitli şartlar dile getirmiş, onlara vakfından ödenek ayırmıştır. Vakıf gelirinden her yıl ayrılacak 4000 akçe ile ramazan Bayramı'nda (muhtemelen bayram öncesinde) dul hanımlara ve yetimlere giyecek alınarak dağıtılmasını istemiştir. Böylelikle toplumca kabul edilen bu önemli günlerde sosyal dayanışma ve yardımlaşmanın güzel bir örneği sergilenmiştir (http://www.vgm.gov.tr/dergiler/bimediz/index.html\#/1/, e.t.: 05.10.2012.).

Yine Osmanlı toplumunda dini bayramlara ve ahlaki değerlere verilen önem vâkıf kişilerce de benimsenmiş, bu günlerle ilgili vakfiyelerinde çeşitli şartlara yer vermişlerdir. Rodosçuk'da Seyyit Ahmet Ağa kızı Hacı Ümmügülsüm Hanım'a ait 1790 tarihli vakfiyede her yıl ramazan ayında et alınarak muhtaç durumdaki fakirlere, yetimlere ve yoksul hanımlara dağıtılmasını istemiştir. Özetle; Vakıfe, üç kadın hizmetçisi ile tanıdığı başka bir hanım için de kurduğu vakıftan ödenek ayırmış, onlara hayatları boyunca yaralanabilecekleri düzenli bir gelir bırakmıştır. Kadınlara bu yardımın vakıf tarafından yapılması, yardımların sürekli ve düzenli olduğunun da göstergesidir (Cunbur, 2006: 207-212).

Yine aynı düşüncede olan başka bir vakıf kurucusu Züleyha Hanım vakfiyesinde; kurduğu vakıftan her yıl vakıf geliriyle kurban alınıp kesilerek etinin muhtaçlara ulaştırılmasını istemiştir. Hatice Sultan'ın İstanbul'da kurduğu "Teravihlerde Kaçkar balından şerbet dağıtan vakfi"”3 Tekirdağ Çorlu'da kurulan Hatice Hatun Binti Hasan Vakfi ${ }^{24}$ (Müftüoğlu, 2012 )kurulan vakıflara örnek olarak tespit edilmiştir.

Hayır işlerinde sınır tanımayan Osmanlı kadını kurduğu vakıflar sayesinde insanlara hatta tüm canlılara hizmetler sunmuş, hayat kalitesini arttırarak, yaşam koşullarının iyileştirilmesini hedeflemiştir. Vakıflar sayesinde yapılan hayır işleri

\footnotetext{
${ }^{23}$ İstanbul'da 1663 M. Tarihinde kurulmuştur. Vakfiyesinde; “......Leyâli-i Ramazan-1 Şerif' de câmi-i şerifin üç adet kapularında şerbet olmadığı içün her sene üç bin vukiye Atina (Rize'in Pazar ilçesi) bal iştira olunup ba'deterâvihcemâât-i müslimineiskâ oluna...."ifadeleri yer almaktadır (Müftüoğlu, 2012).

${ }^{24}$ Her Cuma gecesi yarım keyl (ağırlık birimi) halis undan fodula (ekmek) pişirilip....fukaraya yedirile...." (Müftüoğlu, 2012).
} 
belli zamanlara göre taksim edilmiş; bazı vâkıf ve vâkıfe yardımlarının sürekli olmasını istemiş; vakfiyesinde; her ramazan....,her y1l...vb. ifadelere yer vermiştir. Kimi vâkıfe ise yaptığı yardımlarda süre belirtmemiş devamlı, her gün vb. yapılmasını vakfetmiştir. Konuya bu açıdan baktığımızda şu vakıflarla karşılaşmaktayız. Süreli yardımlar yapılmasını vakfeden vâkıflardan Zeyni Hatun* vakfından, yardıma muhtaç çeşitli gruplara düzenli bir ödenek ayrılmıştır. $\mathrm{Bu}$ ödeneğin yedirip içirme ve üst baş alımı işlerine harcanması vasiyet edilmiştir. Yardım yapılması planlanan gruplar arasında mektep öğrencileri ile fakirlerin yanında dul ve yoksul kadınlarda zikredilmiştir. Vakıfe Hacı Ümmügülsüm Hanım vakfiyesinde özetle; Her yıl Ramazan-1 Şerif ayı geldiğinde yirmişer okka koyun eti satın alınarak mütevelli marifetiyle iki okkasının vakıf kâtibi, câbisi ve yakın akrabalarına, arta kalan on yedi okka koyun etinin yarımşar okka halinde ayrılarak fakir ve muhtaç Müslümanlara, yoksul yetimlere ve ihtiyaç sahibi kadınlara verilerek hayır dualarını istemiştir. Kadınlara bu yardımın vakıf tarafından yapılması, bir bakıma yardımların sürekli ve düzenli olduğunun da göstergesidir. Vâkıfe, üç kadın hizmetçisi ile tanıdığı başka bir hanım için de kurduğu vakıftan ödenek ayırmış, onlara hayatları boyunca yaralanabilecekleri düzenli bir gelir bırakmıştır (Cunbur, 2006:207-212).

Bir başka hayırsever Abide Hatun; Bursa'da tesis ettiği vakfindan bayram arifesinde dul ve yetimlere elbise alınmasını, her Cuma Alaaddin Camii'nde zikredilen dervişlere pilav, zerde, yahni ve şerbet ikram edilmesini, aşure dağıtılmasını istedikten sonra, fakirlerin avarız vergilerinin ödenmesi için de 1.000 akçe tahsilat ayırdığını ifade etmektedir. Yine aynı vakfiyede: bayram arifesinde dul ve yetimlere elbise alınmasını istemiştir. (http://www.vgm.gov.tr/dergiler/bimediz/index.html\#/1/, e.t: 05.10.2012) Bir diğer vâkıfe Züleyha Hanım; kurduğu vakıftan her yıl, kız veya erkek ayırt etmeden yetim ve fakir 15 çocuğa bayramlık elbise alınıp dağıtılmasını, vakıf geliriyle kurban alınıp kesilerek etinin muhtaçlara ulaştırılmasını istemiştir. Vakıf bunun yanında, evli olmayan kadın, kimsesiz ve yaşlılardan on kişiye her yıl ramazan ayı başlarında yüz kuruş para dağıtılmasını da vakıf şartları arasında belirtmiştir (Başol ve Çam, 2010: 196-205). Öz bir ifade ile vakıflar aynı zamanda toplumdaki sosyal yardımlaşma ve dayanışmayı tesis etme ve toplumun bünyesindeki iktisadi dengeyi sağlamaya çalışmaktadır. Bu konuda birçok vakfiye şartına rastlanmaktadır.

Kethüdâ Canfeda HanımVakf,, "ihtiyaç sahibi bekâr ve evlilere ev temin edilmesi, yoksul ve dullara maaş bağlanması"; Sivas'ta "Daru'r Reha Vakfi" da; "Hastalık ve benzeri afet ve olaylar nedeni ile geçim sikıntısına düşerek ihtiyaç ve zaruret içinde bulunan yoksulların, yetimlerin ve dul hanımların ihtiyaçlarının giderilmesini" belirtmiştir.

Yine Kanuni Sultan Süleyman'ın annesi, Hafsa Valide Sultanoğluyla uzun yıllar Manisa'da yaşamış, buraya Sultaniye Camii ve külliyesini yaptırarak; aynı zamanda camiye cemaat toplamak için de çevresinde 20 evlik yer satın almış ve ev yaptırmak isteyenlerden vergi alınmamasını şart koşmuştur (Alpgüvenç, 2010: 35-70).

\footnotetext{
* Zeyni Hatun Binti Kemal Ağa/1588/İstanbul.
} 
Tarihimizde hayır işlerini vazife ahdeden birçok hanım sultanımızda vardır. Hayır ve hasenatta bulunmayı âdeta aşk derecesinde benimseyen Âdile Sultan; Medine'de kurduğu Sebilhâne Vakfı sayesinde açılan kuyular ve inşa edilen sarnıçlar, o bölgenin en büyük ihtiyacı olan suyun sağlanmasına yönelik yapılan vakıf çalışmalarıdır. Örnek bir insan olarak birçok vakıf hizmetlerinde bulunmuştur (Özdemir, 1998). Adile Sultan gibi Hasene Şah Hatun Binti Abdullah $^{25}$ 'da Medine fakirleri için yardımda bulunulmasını vakfiyesinde şart koşmuş̧tur. Hayır işlerinde yarışan bir diğer sultan Mahpeyker Kösem Valide Sultan hakkında Mazak; "fazlasıyla hayırsever olup, borçluları hapisten kurtarır, yoksulları, dul ve yetimleri gözetirdi." tespitinde bulunmuştur.(Mazak, 2009).İstanbul'da yetim ve fakir olan kız ve erkek çocuklarla, evli olmayan kadınlara, kimsesiz ve yaşlılara para, elbise ve yiyecek verilmesine ilişkin 1894 tarihli Züleyha Hanım vakfiyesinde (Müftüoğlu, 2012) her y1l, kız veya erkek ayırt etmeden yetim ve fakir 15 çocuğa bayramlık elbise alınıp dağıtılmasını, vakıf şartları arasında belirtmiştir. 16. yüzyılın ikinci yarısında İstanbul'da yaşayan VâkıfeZeyni Hatun binti Kemal Ăga, vakfettiği akarla 1588 yılında zengin bir vakıf kurmuştur. Zeyn-i Hatun Vakfından, yardıma muhtaç çeşitli gruplara düzenli bir ödenek ayrılmıştır. Bu ödeneğin yedirip içirme ve üst baş alımı işlerine harcanmasını vasiyet ederek; mektep öğrencileri ile fakirlerin yanında dul ve yoksul kadınları özellikle zikretmiş̧ir. İstanbul'da vakıf kuran; Revnak Hanım ${ }^{26}$, Aişe Sıddıka Hanım ${ }^{27}$, Fatma Hatun ${ }^{28}$ benzer konulara vakfiyelerinde yer vermiştir. Yine İstanbul'da 1605 M. yılında bir vakıf kuran Hürrem Ăga bin Abdulmennan vakfiyesinde; her sene güvenilir kimselere 360 akçe verip onlar vasıtasıyla belirli mahalle halkının ihtiyaçlarının karşılanmasını; özellikle vergisini ödeyemeyecek durumda olanların vergilerinin ödenmesini istemiştir. Ayrıca evliya, şehit ve büyüklerin ruhları için Kur'an okunmasını da vakfetmiştir. Zeni Hatun ise 1558 'de İstanbul'da "Serbest bırakılan köleleri kollayan" ilginç bir vakıf kurarak; Azatlı kölelerin fakir ve muhtaç olanlarına bin akçe harcanmasını vakfetmiştir (Müftüoğlu, 2012). Böylelikle toplumda dezavantajlı konumda olan bireylerin sosyal uyumuna yardımcı olunmuş, daha sağlıklı bireyler olarak hayatlarını devam ettirmelerinde destek sağlanmıştır. Bu bağlamda Osmanlı kadının sosyal tabaka ayrımı yapmadığı, toplumun tüm kesimi için ihtiyaç gözetilerek vakıflar kurduğu gözler önüne serilmektedir.

Vakıfların bu derece gelişmesi ve yaygınlaşmasında şüphesiz İslam dininin temellerinde yer alan yardımlaşma ve ihtiyacı olanlara destek olma fikri yer almaktadır. Bu konuda bize örnek olan en büyük şahsiyet Peygamberimiz Hazreti Muhammed Mustafa'dır (sav). Bunun bilincinde olan çoğu vakıf kurucusu

\footnotetext{
${ }^{25}$ Yıllık gelirden her y1l 100 kuruş Haremeyn-i Şerifeyn fakirlerine ulaştırmak istediğini vakfiyesinde belirtmiştir. (Mazak, 2009).

26 İstanbul'da bir vakıf kurmuştur. Bu vakfin vakfiyesin de: "Fazla-i merkume ile fukara-i etfal-i müslimin için münasip elbise iştira ve etfal-imerkumeyeilbas ita oluna..." ifadelerine yer vererek; vakıf harcamalarından arta kalan para ile fakir çocuklar için elbise alınıp giydirilmesini şart koşmuştur.(Başol ve Çam, 2010: 196-205).

${ }^{27}$ İstanbul da 1865 tarihinde bir vakıf kurarak; vakıf gelirinden yılda 6000 kuruşun, evlenmek isteyen yoksul klzların düğün elbiselerine, büyük kadınlardan ise giyim kuşamına ihtiyacı olanlara elbise alımına harcanmasını şart koşmuştur. (Başol ve Çam, 2010: 196-205)

28 Hacı Hüsrev Mektebi'nde okuyan on beş yetim çocuğu "her sene şehr-i ramazan-1 şerif geldikteleyleikadir'de bir bogası kaftan ve bir kıt'a takke ve bir don ve bir gömlek ve bir papuç alıverile" ifadeleri yer almaktadır. (Çataltepe, 1991:40-47).
} 
yaptıkları her hayırda ona; dualar, Yasinler, mevlitler hediye etmeyi unutmamıştır. Onlardan biri de Adile Sultandır. Adile Sultan Medîne' de icrâ edilecek mevlid merâsimi için 20 Osmânî lira, Medîne'deki on dört hâneli ribatta ikâmet ettirilen muhtaç kadınlara verilmek üzere 56 sîm mecidiye, yine Medîne'de diğer yedi hânede oturanlara verilmek üzere 63 sîm Mecidiye ve Mekke'de Muhammed Can Efendi dergâhında senede bir defa okutulacak mevlid masraflarına harcanması için 30 Osmânî lira olmak üzere toplam 7261 kuruş, Surre-i Hümâyun ile Mekke ve Medîne'ye ulaştırılmak üzere, hazîneye teslim edilmiştir.(Mazak, 2004: 123-138).

\section{"Gale-i merkumeden beher sene şabanü'lMuazzamanınevahirinekarib} ..."

Adile Sultan özellikle Mekke ve Medîne'ye ulaştırılmak üzere, belirlediği emanetleri Surre-i Hümâyûnun hareket tarihi olan Şaban ayının on beşinci gününden bir ay önce hazîneye teslim etmesindeki detay dikkat çekicidir. Adile Sultan'ın bu örnek davranışı öyle anlaşılmaktadır ki kadının toplumdaki saygın yerini alabilmede öncü bir davranış olarak etki göstermektedir (Mazak, 2000: 54).

Vakıflar bulundukları toplumun özellikleri, yapısı, eğitimi, gelenekleri doğrultusunda hizmet vermiştir. Halk, ihtiyaçlarının büyük bir kısmını vakıfların çeşitli hizmetleri sayesinde karşılamıştır. Osmanlı kadını yaşadığı toplumdaki değişimlerin farkında ve ihtiyaçlarını ona göre şekillendirerek karşılamaya çalışmıştır. Bu hizmetlerden biride sağlık hizmetleridir. Sağlık hizmetlerine baktığımızda hanım sultanların yine hem yurtiçi hem de yurt dışında birçok hayratları olduğu görülmektedir. Özellikle bayanlara yönelik yapılan bu hayratlar toplumda hususi bir yere sahiptir. Sultan Abdülaziz'in Annesi Pertevniyal Valide Sultan, Medine-i Münevvere'de sadece kadınların istifadesi için 400 yataklı, kaloriferle isıtılan, modern ve büyük bir vakıf hastane(Kaloriferli ilk hastane) yaptırarak örnek, (numune-i imtisal) hayırsever bir Türk kadını olduğunu göstermiştir (http://www.zaman.com/mainAction.action, e.t.:12.02.2010) .

Bezmi Alem Valide Sultan; devletin kendisine tahsis ettiği imkânları, fakirleri doyurarak, onların ihtiyaçlarını gidererek, yardıma muhtaçları her zaman gözeterek hayır işlerine imza atmıştır. Vakıf Gureba Hastanesi'ni ${ }^{29}$ kurarak birçok ihtiyaç sahibinin faydalanmasını sağlamıştır. Ayrıca onun eserleri arasında Mekke'de "Guraba-i Müslimîn Hastahanesi” de yer almaktadır (Kazıcı, 2005).

Tarihimizde pek çok örneğini gördügümüz vakıf kurumlarının kültürel yönüne de dikkat çekmekte fayda vardır. Vakıfların toplumdaki en büyük fonksiyonlarından biri de Aile konusudur. Aile bütünlüğü, aile kurma, evlilik, ev sahibi olma vb. konularda birçok vakıf kurulmuş, bireyin toplumdaki yaşam kalitesi arttırılarak, sosyal adalet sağlanmaya çalışılmıştır. Ayrıca Osmanlı kadının sosyal hayatın bizzat içinde yer alması, içinde bulunduğu toplumun eksik ve ihtiyaçları konusunda yeterli bilgiye sahip olması kamusal alandaki aktifliğine de vurgu yapmaktadır. Kurduğu vakıflarla toplumun ihtiyacı olan konularda yapıcı

\footnotetext{
${ }^{29}$ Burada "Vakıf Gureba Hastanesi" vakfiyesinde geçen "limonun tanesi 1 sarı altın bile olsa, hastalar için mutlaka alınmalı" ibaresini belirtmek yararlı olacaktır. Bu ifadeler; Bezmi Alem Valide Sultanın yaptığı hayır işlerindeki bu detay dikkat çekicidir. Bireyin toplumda kendini değerli hissetmesi ve yaşadığı problemlerin üstesinden gelmesine destek sağlayarak sağlıklı toplumların oluşumunda model olduğu açıkça görülmektedir.
} 
çözümler üretmişlerdir. Bekâr Fakirleri evlendiren vakıf kurucusu olan İsmihan Sultan'ın vakfiyesindeki şu ifadeler çok manidardır:

“Allah rızası için yapmayı arzuladığım şeyler var... Fakir kızlarımızın düğ̈̈nlerine yardımcı olmak; mutlu olacakları yuvalarını kurmak; yetim kızlar ve dul kadınlarımıza kol kanat germek; onların da bizim gibi yüzlerini güldürmek istiyorum ki bu hizmetler için malımı vakfedeyim”. Bu vaklf yoksulluk sebebiyle evlenmekte güçlük çeken bekârların evlenme masrafinı üstlensin; eğer evlenmek istemeyenler olursa onlara da para ve eşya yardımında bulunsun. Yeter ki mağdur olmasınlar... "(Alpgüvenç, 2010: 25-40).

$\mathrm{Bu}$ niyetlerle kurduğu vakıf sayesinde özellikle fakir kızların müşkülatını gidermiş, mutlu bir yuva kurmalarına vesile olmuştur. İstanbul'da Sadrazam Şem'i Efendi'nin eşi olan Abdullah Kızı Revnak Hanım ise "vakıf gelirinden yılda 6000 kuruşun, evlenmek isteyen yoksul kızların düğün cemiyetleriyle elbiselerine harcanmasını" şart koşmuştur. Yine Nakibû'l-Eşraf Esat Efendi, vakıf gelirinden her yıl, ihtiyaç sahibi bir kızın çeyizinin alınıp hazırlanmasını şart koşmuştur. Mikro düzeyde sosyal hizmeti andıran bu hayır çalışmaları; insanların yaşamlarını zenginleştirme, sosyal ilişki kurma becerilerini geliştirme gibi birçok konuda bireye katkı sağlamaktadır. Öyle anlaşılmaktadır ki; Osmanlı kadını toplumda ailenin önemini kavramış, aile kurma konusunda bireylere destek sağlayarak; diğer bireylere göre dezavantajlı konumda hayatını devam ettirenlerin her zaman destekçisi olmuştur.

Burada Mahpeyker Kösem Vâlide Sultan'ın gayretlerini ifade etmek faydalı olacaktır. Evlenme çağındaki yetim kızları bulup onlara çeyizle birlikte, oturacak ev ve eşya da vererek evlenmelerini sağlamıştır. Mazak'ın ifadelerine göre; Mahpeyker Kösem Vâlide Sultan kendisine hizmet eden câriyeleri iki-üç y1lsonunda, eski saray görevlileri veya münasip mevkilerde kimselerle evlendirip, evlendirdiği erkeğe de, geçimini sağlayacak bir dirlik verirdi. Evlendirdiği kızlara çeyiz, mücevher ve bir kaç kese altın verip ayrıca onlara maaş bağlatır, bayramlarda ve özel günlerde altın keseleri hediye ederdi (Mazak, 2009). Yine başka bir sultan Bezmiâlem Valide Sultan ise; Mahalle aralarında dolaşarak, yetim ve kimsesiz kızları bizzat kendisi tespit ederek, onları evlendirmeyi bir hizmet olarak gerçekleştirmektedir (Alpgüvenç, 2010: 30-42). Burada Osmanlı kadınının kamusal alandan dışlandığı, toplumsal hayattan tecrit edildiği ifadelerini hatırlatarak; farklı tespitleri gözler önüne sermek isteriz. Benzer hayır çalışmaları erkek Vâkıflar tarafından da gerçekleştirilmiştir. Molla Çelebi ${ }^{30}$, Kazasker Mehmed Efendi bin Abdullah ${ }^{31}$ ve Abdullah oğlu İbrahim Bey' ${ }^{32}$ bunlar arasında sayabiliriz. Zikredilen vakfiye şartlarına dikkat edildiğinde yaşam koşullarının iyileştirilmesi hedeflenerek çeşitli yardımlar yapılmış; aile kurmada, düzenli bir hayata sahip olmada en önemlisi toplum hayatına uyum sağlamalarında

\footnotetext{
${ }^{30}$ Hicri 977 tarihinde öksüz ve yetim kalmış kız çocuklarını düşünerek bir vakıf kurmuş, Bu kız çocuklarının evlenebilmeleri ve çeyiz hazırlıklarının yapılması için vakfiyesinde şartlara yer vermiştir (Çataltepe, 1991: 36-43).

31 "Üç yetim kızın, diğer kızlarınki gibi çeyizlerinin hazırlanması için yılda 10.000 dirhem verilmesini, bu paradan artan olursa, kızların evlendikten sonra doğacak çocukları arasında paylaştırılmasını ve bunun böyle sürüp gitmesini şart etmiştir (Müftüoğlu, 2012: 65-71).

${ }^{32}$ Köleleri evlendiren bir vakıf kurarak; kölelerin aralarında evlendirilmesi ve masraflarının vakıf tarafından karşılanmasını şart koşmuştur (Müftüoğlu, 2012: 65-71).
} 
destek sağlanmıştır. Bu perspektiften bakıldığında günümüz sosyal hizmetlerinin hedefleri arasında yer alan ilkelerle örtüşen bu desteklerin altını çizmekte fayda görülmektedir. Yapılan desteklerin devamı anlamında kurulan "Aile içi uyum vakfı" örneği ne de hayranlıkla zikrediyoruz. Bu vakıf evde kırılan eşyanın yerine yenisini koyarak karı-koca arasındaki anlaşmazlığın telafi edilmesi için kurulmuştur (Müftüoğlu, 2012: 65-71).

Toplumdaki bir diğer önemli meselede barınma sorunudur. Evrensel insani değerlere sahip Osmanlı kadını ve erkeği bu konuda da toplum için faydası olacağı mülahazasıyla birçok çalışma yapmıştır. Fatma Hatun kurduğu Vakıfla; Vakfettiği evlerde fakirlerin ve dul hanımların oturmasını, adı geçenler otururken binada onarım gerekmesi halinde vakıfça bu onarımın yapılmasını şart koymuştur (Tuncay, 1984: 40-45). Kethüdâ Canfeda Hanım Vakfiyesi'nde, "ihtiyaç sahibi bekâr ve evlilere ev temin edilmesi" şartını görüyoruz. Hayırda yarışan Hoca-i Sultani Vakfının Vakfiyesinde; yaptırdığı Darü'l-hadis müderrislerine meşrut Birgi'de meyveli meyvesiz bahçe ve sair müştemilatı bulunan kışlık ev ile Bozdoğan'da yazlık evi kullanmaları için vakfettiği görülüyor. İstanbul' da kurulan Vildan Hatun; Balat sahilinde bir dinlenme evi (tesis) yapılmasını vakfetmiştir. Halkın yaz, kış istedikleri zaman buraya gelip konaklamasını, Haliç'in eşşiz manzarası eşliğinde istirahat edebileceklerini vasiyet etmiştir. Neslişah Sultan ise; işinden ayrılmış; hasta, fakir, kimsesiz ve yaşlı hizmetlilerin barınması için Kasımpaşa' daki bir konağı bu vakıf için vakfetmiş̧ir. Birçok kimsenin ev sahibi olmasını sağlamıştır (Müftüoğlu, 2012: 65-71). Yeri gelmişken özel bir hamamdan bahsetmeden geçemeyeceğiz. Gedik Paşa Hamamı; İstanbul hamamları içerisinde özel bir yere sahiptir. Gedik Paşa Hamamı'nın külhani, evsizlerin barınmaları açısından oldukça müsait bir tarzda yaptırılarak barınma amaçlı kullanımı gerçekleştirilmiştir (Yazıcı, 2007: 1-46). Burada Hafsa Sultanın hayratı da konuya farklı bir bakış açısı getirmektedir. Daha önce ifade edilen Camii ve külliyesi ile ilgili olarak; camiye cemaat toplamak için çevresinde 20 evlik yer satın almış ve ev yaptırmak isteyenlerden vergi alınmamasını şart koşmuştur (Alpgüvenç, 2010: 5065). Manisa'ya bir de evsizlerin ve yolcuların kalması için hankah inşa ettiren Sultan, yaptığı bu eser makro düzeyde bir sosyal hizmete vesile olarak; şehirde düzenli ve planlı bir yerleşimin gerçekleşmesini sağlamıştır. Bireylerin toplumla iç içe barışık bir hayat sürmelerin de rol oynamıştır. İnsan ve toplum faktörünün sürekli değişim gösterdiği düşünüldüğünde ileriye dönük yapılan bu çalışmalardaki detaylar dikkat çekicidir. Toplum düzeninin temininde bu tür çalışmalar takdire şayandır.

Toplumda mağdur olan bir grubu da yaşlılar oluşturmaktadır. Neslişah Sultan kurduğu yaşlı kadınlara ev tahsis eden vakfın vakfiyesinde: işinden ayrılmış; hasta, fakir, kimsesiz ve yaşlı hizmetliler için Kasımpaşa'da bir ev tahsis edilmesini şart koşmuştur. Yine barınma ile ilgili çok faydalı vakıf çalışmasına Adile sultan da imza atmıştır. Adile Sultanın vakıfları içinde, belki en önemlisi ve en ilgi çekeni, Medine'de sadece kimsesiz ve çaresiz kadınların ikamesi için vakfettiği hanelerdir. Medine'de, muhtaç kişilerin barınması için kurulan menziller de bu vakfın hizmet alanına giriyordu. Adile Sultan yaptığı bu hayrat ile çaresiz, sahipsiz kadınlar için sığınma evi açarak Osmanlı tarihinde bir ilke imza atmıştır (Uluçay, 1985: 138). 
Osmanlı toplumunda her alanda karşımıza çıkan vakıflar İș ve İstihdam alanında da görülmektedir. Muvakkithane ve camilerdeki saatlerin bakımı için kurulan ilginç bir vakıf Ayșe Hanım Binti İsmail Efendi Bin Abdullah Vakfıdır. $\mathrm{Bu}$ vakıf, bu işi yerine getirecek kişiye maaş bağlamış, bu işi yapacak kişilerinde uzman olmasını özellikle belirtmiștir (Müftüoğlu, 2012:33-37). İnegöllü Zade Saffet Bey'in kuruduğu; türünde ilk ve tek olan bir vakıf: Erâmilhâne (Dullarevi)dir. Bursa'nın eşrafından ve Duhter Şeref Mahallesi sakinlerinden olan ve şehitlerin geride bıraktıkları eşlerini görüp gözetmenin milli ve dini bir görev olduğunun farkında olan bu hayırsever insan, Bursa'nın Osmangazi İlçesinin Alaca Hırka Mahallesinde bir bina yaptırarak şehitlerin dul eşleri ile kimsesiz ve meskensiz diğer dulların barındırılmasına tahsis etmiş̧tir. Ayrıca dullar evinde kalan hanımlar için bina içinde dokuma tezgâhlarının yer aldığı bir salon düzenleyerek atölye oluşturulmuştur. İsteyen kadınlar burada çalışarak gelir elde edebilmekteydi. Bu uygulamadaki detaylar Osmanlı kadınının konumu açısından dikkat çekicidir (Ateş, 1995: 25-31). Saffet Bey'in gerçekleştirdiği bu hayır işi sosyal adaleti amaçlayan fevkalade bir uygulamadır. Dezavantajlı bir grubu toplum gözünde yücelterek diğer bireylerle aynı standartlarda, toplumdaki rolünü ifa etmesi için desteklemektedir. Burada bir kez daha Osmanlı toplumunun gelenek, görenek, örf ve ananelerine ne kadar bağlı ve saygılı olduğunun altını çizmekte fayda görmekteyiz. Bu bağlamda Saffet Bey; yaptığı bu hayırla kadınların barındırılmasında destek sağlamanın yanında onları evlatlarından ayırmadan hem bir aile ortamında kalmalarını sağlamış hem de iş imkânı da oluşturmuştur.

Sosyal yardım amaçlı kurulan vakıflardan birçok insan yararlanmış, İş İmkânı sağlanmıştır. Sivas’ta bir ev ve bahçe vakfederek vakıf kuran Hattab bin Sahib Ahmed vakfiyesinde:"

"Herhangi bir kaza veya bela sebebi ile borçlanma durumunda kalanlara kefil göstermek şartıyla borç verilmesi; ancak varlığını haram olan işler ve amellerde harcayarak muhtaç duruma düşenlere borç verilmemesi, muhtaç olan dul ve yaşlı hanımlara her ay iyi atılmuş pamuktan birer okka pamuk, ihtiyar olan erkeklere birer dirhem para verilmesi, âmâlardan muhtaç olup da mahalle ve sokaklarda, çalışamayacak durumda olanlara yillık 2050 dirhem tahsis edilmesi" şart koşulmuş.

Bundan 700 yıl önce kurulan vakfin işlevleri arasında ihtiyaç sahibi olan hanımlara, kendi evlerinde iş temini sağlamak yer almaktadır. Yün, pamuk ve benzeri hammaddeler alınarak, bu hanımlara evlerinde veriliyor ve evlerinde yapılan faaliyet karşıllğında ücret ödeniyordu. Seçilen bu hanımların özellikle savaşta şehit olan asker eşlerinden seçildiği varsayılmaktadır. Yine, Karaçelebizâde Mehmed Efendi “..fisk u fücurdan âriutekalarının dul kadınlarına senevi 200 akçe..." verilmesini vakfetmiştir. Ahmet ibni Rahat'ın kurduğu vakfında ise; "....muhtaç olan dul ve yaşlı hanımlara her ay iyi atılmış pamuktan birer okka pamuk verilmesi....." ifadeleri yer almaktadır (Gülsoy, 2012).

Vakıflar sayesinde düzenli yardımlarda bulunan Vâkıf ve Vâkıfeler toplumda korunmaya muhtaç olarak gördüğü bir gruba bir nevi kurduğu vakıf aracılığıyla kurumsal olarak yardımda bulunmuş oluyordu. Öz bir ifade ile Osmanlı kadını kamusal alanda varlığını her zaman sürdürmekteydi. Hümanist bir 
yaklaşımla ayırım yapmadan herkes bu imkânlardan yararlanabilmekteydi. Vakıfların sunduğu hizmetlerden herkesin yararlanmasına rağmen bunu yeterli görmeyen Vakıf ve Vâkıfeler; yaşadıkları çevrede, semtte, mahallede bulunan ihtiyaç sahipleri için vakfiyelerinde özel şartlara yer vermiştir. Bu şartlar arasında özellikle kadınları unutmamışlardır. Bunlardan biri; 16.yüzyılda İstanbul da yaşayan Hacı Rüstem bin Abdullah,1545 tarihli vakıftı. Vakfiyesinde;

"Daye Hatun mahalle sakinlerine senede yüz dirhem, Daye Hatun Mescidi mütevellisine senede dört yüz dirhem cübbe, kavuk, pabuç ve sair elbise parasını yine muhtaç fakir ve yoksul çocuklarının giydirilmesini ve senede iki yüz dirhem dört nefer dul kadına verilmesini de vakfetmiştir."

Hayır işlerinde yarışan kişiler kendi güçleri yettiğince toplumda faydalı işler yapmaya çalışmışlardır. Nakdi yardımları da unutmayan hayırseverler birçok vakıf şartnamesinde bu konuya da yer vermiştir. Yaşadığı dönemde, İstanbul'da sıbyan mektebi hocası olan Hacı Mehmet Tahir Efendi'nin vakıf şartlarına göre vakfın bütün masrafları çıktıktan sonra gelir fazlasının dörtte biri vakıf malına eklenecek geriye kalanı ise dul hanımlara, yetimlere ve yoksul durumdaki kişilere eşit olarak dağıtılacaktır.

Osmanlı döneminde özellikle kadınlar tarafından kurulmuş pek çok sıbyan mektebi, medrese vb. eğitimi destekleyen kurumlar karşımıza çıkmaktadır. Turhan Sultan döneminde Valide Camii olarak adlandırılan, günümüzde Eminönü’ndeki yeni cami olarak bilinen camii tamamlattırmıştır. Değerli kitaplardan oluşan bir kütüphane vakfetmiştir. Hanım Sultan Bezm-i Âlem, yaptırdığı Valide Mektebi içinde bir Litografya matbaası ve bugün Beyazıt devlet kütüphanesine devredilmiş olan zengin bir kütüphane vakfetmiştir. Ayrıca Dolmabahçe Camii, mektebi ve çeşmesini de Bezm-i Âlem Valide Sultan yaptırmıştır. Pertevniyal Valide Sultan İstanbul'un pek çok semtine çeşmeler yaptırmıştır. Aksaray'da bir külliye yaptırmış, kütüphanesine birçok kitap vakfetmiştir. Külliyenin bazı bölümleri ne yazık ki günümüze kadar ulaşamamıştır (Toska, 1999). Sultan Birinci Murad Han'ın Hanımı Gülçiçek Hatun Bursa'da bir medrese ve camii yaptırmıştır (Pazan, 2011:43).

Osmanlı kadınının yaptığı en önemli vakıflar, okullar için yapılanlardır. Başbakanlık arşivindeki kayıtlara göre İstanbul'da kadınlar bir çok okul kurmuştur: Asude Hatun Mektebi, Ayni Hatun Mektebi, Hace Ayşe Hatun Mektebi, Belkıs Hatun Mektebi, Fesahet Kadın Mektebi, Gaybi Hatun Mektebi...vb. yüzlerce okul kadınlar tarafından yaptırılmıştır. Bu örnekler Osmanlı kadınının eğitime verdiği önemin altını çizmektedir (Savc1, 1973:40-49).

\section{Osmanlı Toplumunda Kadının Sosyal Hizmet Alanındaki Rolü}

Osmanlı döneminde vakıflar yaptıkları hizmetler itibari ile bir nevi beledi ve sosyal hizmet kuruluşu görevini üstlenmiştir. Araştırmamız sırasında; ihtiyaç sahiplerine yapılan yardımlar, çevre temizliği, yoksulun doyurulması, hastaların tedavisi vb. birçok alanda hizmet veren özellikle hanım vakıflarının çok yönlü bir sosyal hizmet çalışması yürüttüğü tespit edilmiştir. Bu bağlamda kıt imkânlarla hayatını sürdürmeye çalışan bireylere kucak açarak, toplumdan tecrit edilmeden 
insan onuruna yakışır bir şekilde hayatlarına devam etmeleri ve sosyal barışın huzurla devamının sağlanmasında örnek model olmuşlardır (Öztürk, 1995: 42-47).

Osmanlıda kadın yaşadığı kırsal ya da kent merkezine göre her zaman toplum içinde yerini almıştır. Kırsalda özellikle doğrudan üretime katılarak; avrat pazarı denilen pazarlarda tarımsal ürünlerden el işlerine kadar birçok ürün satabilmekte iken; bohçacılık yaparak, ev ev dolaşarak da çeşitli ürünleri satabilmekteydi. Araştırmamız sırasında Osmanlı kadınının daha sonraları kalifiye eleman olarak imalathanelerde çalışmaya başladığı tespit edilmiştir. Özellikle iplik imalathanelerinde birçok kadının çalıştığı tarihi belgelerde yer almaktadır. Bunların dışında Osmanlı kadını kendine çeşitli çalışma alanları oluşturmuştur. Çamaşırcı kadınlar bu konuda bir örnektir. Ayrıca dolmalar, sarmalar yapıp satan kadınlara da arşiv belgelerinde rastlanmaktadır. Yine dokuma tezgâhları kadınların en çok çalıştıkları iş alanlarıdır (Davıs, 2006: 160-168).

Bunun yanında vakıflar ise Osmanlı kadının rol aldığ alandı. Kadınların vakıf kurma yanında yönetici olarak da görev yaptığı müesseselerdir. Öz bir ifade ile kadın toplumdaki sosyal rolünü tercihine göre şekillendirmekteydi. Buda Özgürce kararlar alabildiğinin göstergesidir. Toplumda çeşitli vakıflar kurarak sosyal çatışmayı engelleyen Osmanlı kadınının bu hizmetleri "Koruyucu Sosyal Hizmetler" perspektifinde değerlendirilebilmektedir. Nitekim sağladıkları imkânlarla bu çatışmalara engel olunmuş, toplumdaki huzura katk1 sağlanmıştır. Özellikle gelir düzeyi yüksek kişilerce sağlanan bu hayırlar; gelir dengesizliğinin toplumda oluşturacağı kaosu engellemektedir. Kurban Bayramında kurban kesip dağıtan, bayramlık eşyalar hediye eden Zeliha Hanım; Ramazan Bayramında dul hanımlara ve fakirlere bayram öncesi kıyafetler alınıp dağıtılmasını isteyen Abide Hatun bu amaçla vakıflar kurarak; karşılaşılabilecek sorunları önleyerek, dezavantajlı konumdaki bireylere destek sağlamışlardır.

Yine Osmanlı kadını, kurduğu vakıflarla sahip olduğu kültür ve değerlerin aktarımına da katkıda bulunmuştur. Bir nevi Kültürel Sosyal Hizmet gerçekleştirerek, özellikle yeni fethedilen yerlerdeki insanlara da Osmanlı adet, gelenek ve göreneklerin aktarılarak daha bilinçli toplumların hayat bulmasına destek olmuşlardır. ${ }^{33}$ Kültür hazineleri, bazı kitapları vakfederek kütüphaneler kurmuş; bu bilgilerin tekrar tekrar okunarak canlı kalmasını ve kültürel değerlerin yaşatılmasını sağlamıştır. ${ }^{34}$

Osmanlı kadını kurdukları vakıflar sayesinde yaşadıkları toplumda istihdam sağlamış, birçok kişinin sürekli bir gelire sahip olmasına vesile olmuştur. Kurdukları vakıflara kadın mütevelliler tayin ederek iş imkânları oluşturmuştur. Osmanlı kadını gibi erkekleri de kadınlar için istihdam imkânları sağlamıştır. Ev ve bahçe vakfeden; Hattab bin Sahib Ahmed, dokuma tezgâhları vakfeden İnegöllü zade Saffet Bey örneklerden sadece birkaçıdır. Ayrıca yaptıkları hayırlarla ülkemize gerek mimari eser gerekse hayır kurumları kazandırmışlardır. Yaşanılan mekânın imarında da önemli izler bırakmışlardır. Kurdukları hayır vakıflarının

\footnotetext{
${ }^{33}$ Bosna'da kurulan Şahdîdâr Hanım, Dudi Bula, Hatice Hatun vakıfları ve Kıbrıs'ta kurulan; Gülsüm Bint-i Derviş, Cemile bint-i Abdülkadir Hatun, Hatice Hatun vakfı bunlara bir örnektir.

${ }^{34}$ Mihrümah Sultan, Turhan Sultan, Pertevniyal Valide Sultan gibi.
} 
sadece bugünün değil daha sonraki yıllardaki durumunu da düşünülerek tamir, onarım bakım işleri için de vakfiyelerinde yer vermeleri Osmanlı kadınının yarınları da düşünerek ölümsüz eserler bırakmak istediğini gözler önüne sermektedir. Aynı zamanda vakıf müessesesini kurarak istihdam sağlama yanında bakım ve onarım şartları ile de ek bir istihdam imkânı oluşturmuşlardır.

Osmanlı kadını kurduğu vakıflarla birçok insanı aynı duygu ve düşüncede bir araya getirerek hayır işlerini şart koşmuştur. $\mathrm{Bu}$ da toplumdaki sınıfsal farklılıkları en aza indirgeyerek müreffeh bir toplum oluşmasında etkili olmuşlardır. Saliha Hatun'un kurduğu vakıf ile haçlıların eline esir düşen Müslümanları kurtarma ve ihtiyaçlarını karşılama isteği, serbest bırakılan köleleri kollayan vakfını kuran Zeyni Hatun bu konuda örnek vakıf kuran Osmanlı kadınlarındandır. Günümüz sosyal hizmetlerin yapmaya çalıştığı sosyal adalet ve sosyal barışa daha o yıllarda zemin hazırlanmaya çalışılmıştır. Oluşturulan bu sosyal bütünleşme sayesinde kurulan vakıflar etrafinda yerleşilen mahalleler toplumda bir düzen oluşturmuş, tüm sosyal ihtiyaçlar yerinde karşılanmıştır. Yaşanılan yerleşim merkezlerinde toplumsal bütünleşme rahatlıkla gerçekleştirilmiştir. ${ }^{35}$ Bir nevi sosyal katalizör rolü ${ }^{36}$ üstlenmişlerdir.

Osmanlı kadını kurduğu vakıflarla erkeklerden geri kalmamış hatta daha da ileri giderek çok ince detaylara dikkat ederek duyarlı vakıflar kurmuşlardır. Yeri geldiğinde tebdili kıyafet ederek halk arasına karışıp ihtiyaçları bizzat gözlemlemiş birçok hanım sultan vardır. ${ }^{37}$ Kurdukları vakıflarla toplumda bir sevgi ve saygı bağ oluşturulmuş, bir nevi toplumun manevi mimarı olmuşlardır. Öyle anlaşılmaktadır ki; Osmanlı kadını toplumun her kesiminde kurduğu vakıflarla hayat bulmuştur.

\section{Sonuç ve Tartışma}

Osmanlı toplumunda çok sayıda vakıf kurulduğu bilinmektedir. Hayır ve hasenatta bulunan kişilerce kurulan bu vakıflar içinde kadınlarca kurulan vakıfların ayrı bir yeri vardır. Ailenin korunmasından aile fertlerinin dayanışmasına, kadınlardan dul hanımlara, yaşlılardan genç kızlara kadar birçok kesimi alakadar eden bir amaca hizmet etmiştir. Bu bağlamda; toplumdaki sosyal ilişkiler de kurulan vakıflardan etkilenmekte, kişi kendi için istediğini başkaları için de isteyerek duyarlılık sergilemektedir. Bu durumun yaşanılan topluma olumlu yansımaları elbette kaçınılmaz olacaktır. Kurulan bu vakıflar sayesinde toplumsal ilişkiler ve gündelik hayattaki birçok sorun çözümlenerek, toplumun tüm kesimlerinde rol alan kadınlar toplumdan dışlanmamış, vakıflar sayesinde kendilerine sahip çıkılmış, güven içinde yaşamışlardır (Ateş, 1995:25).

Yaptığımız mütevazı incelemede gördük ki; daha önce ifade edilen birçok araştırmacı, Osmanlı kadınını yalnızca kocalarının malı olarak görmektedir. Bu bağlamda farklı bakış açıları ile Osmanlı kadınını bir kez daha incelemekte fayda

\footnotetext{
35 Hafsa Sultan Manisa'da külliye yaptırarak, çevresinde yirmi evlik yer alarak ev yaptırmak isteyenlerden vergi alınamamasını şart koşmuştur.

${ }^{36}$ Halim Baki Kunter'in ifadesi.

37 Örneğin; Adile Sultan, Bezmiâlem Valide Sultan gibi.
} 
görülmektedir. Osmanlı kadını düşünülenin aksine yaşadıkları toplumda gariban, zayıf üyeler olarak yer almamış, aksine son derece önemli rolleri ifa etmiştir. Birçok vakıf kurma yanında mütevelli vazifesini de yerine getirerek; hem işveren hem de çalışan konumunda sosyal hayatta rol almıştır. Toplum hayatında çok görünür olmaması ya da Osmanlı kadını ve vakıfları hakkında yeterince araştırma yapılamaması böyle bir tablonun ifade bulmasına gerekçe olmamalıdır. Ayrıca konuyla ilgili verileri yorumlamadaki farklılıklar yapılan araştırmalarda farklı bakış açılarının oluşmasına neden olmuştur. Öyle anlaşılmaktadır ki, çok karmaşık etkiler bazı noktaların gözden kaçmasına sebep olmaktadır. Osmanlı toplumunda hanedanlardan toplumdaki en alt tabakadaki kadınlara kadar hepsi vakıf kurmuştur. Kurulan her vakfın gelir ve bağışının farklı olması bize hem varlıklı hem de mütevazı hayata sahip birçok kadının vakıf kurduğuna işaret etmektedir.

Yaşadığ1 toplumun ihtiyaçlarının farkında ve çözüm için çaba gösteren Osmanlı kadını toplumda sadece belli bir kesimi düşünmemiş tüm toplumu kucaklayan evrensel bir tavır ile hayır işlerini gerçekleştirmiş, öncü kadınlardır. Bu da toplumdaki sosyal bütünleşmenin gerçekleşmesinde "Önleyici Sosyal Hizmetler" duyarlılığını hatırlatmaktadır. Öz bir ifade ile Osmanlı kadını yaşadığı toplumla iç içe bir hayat sürmüş, müreffeh bir toplum için gayret göstermiştir. Örneğin yaşadığı dönemde mahalle çeşmelerinin ve suyollarının ne kadar önemli olduğunun idrakine varmış olacak ki; o dönem yüzlerce çeşme ve sebiller yaptırmış, soğuk sular dağıtılmasını vakfetmiştir.

Tarihimizde çok önemli bir yere sahip olan vakıf kurumları, Osmanlı kadını sayesinde bu önemini daha da pekiştirmiştir. Toplumun manevi mimarları olarak her dönem hayat bulmuştur. Kadınlar Yardımlaşma ve dayanışmanın toplumda varlık bulmasına kurdukları vakıflarla aracılık etmiş, sosyal hayatta aktif rolünü ifa etmiştir. Dolayısıyla toplum hayatından tecrit edildiği iddialarının doğruluğunun tekrar sınanması gerektiği düşünülmektedir.

Kurulan vakıfların çoğunda özellikle kadın mütevellilerin tercih edilmesi onlara hem bir iş hem gelir sağlamaktadır. ${ }^{38}$ Aynı zamanda hak sahibi olması, hem de kuşaklar arası maddi-manevi aktarımın olması kadınlara ayrı bir önem sağlamaktadır. Ayrıca erkeklerin kadınların kurduğu vakıflara her zaman destek olması, yapılan bu hizmetlere onay verdiklerini göstermektedir. Bu bağlamda kadınlar gerek aile içinde gerekse toplumda hatırı sayılır bir konuma sahip olmuşlardır.

O dönem çok kıymetli olan kitapları bulmak oldukça zordu. Osmanlı kadını bu ihtiyacı da fark ederek, herkesin kitaplardan faydalanması niyetiyle sahip oldukları kitapları da vakfetmişlerdir. ${ }^{39}$ Vakıflar; kadınların hem mal varlığını, hem sahip oldukları malları yönetme ve yararlanma hakkının bir göstergesidir. 1172 yılında Emir Rıdvan Ağa'nın kızı es-sit Ayşe Hanım; su çarkları, bir firın, bir değirmen ve sayısı belirtilmeyen mekânlar vakfetmiştir (Any Fay, 2000: 27-40). Bu veriler ışığında Ayşe Hanımın zamanın en zengin kişileri arasında olduğunu

\footnotetext{
${ }^{38}$ Hacı Mehmet Kızı Emine Hatun Vakfi/1844/Kütahya. Her sene 120 şer kuruş, Kütahya'nın İrmez köyü civarındaki toplamda 3 çeşmenin tamirine harcansın. Kalan fazlasını mütevelli elinde tutabilir. Ben öldükten sonra Azime ile Hatice ve sonra onların nesilden nesile evlatları mütevelli olsun." (Zeyrek Soyer, 2007).

${ }^{39}$ Balıkesir'de Fatma Hanım Akbıyık camiinde kitaplarını bir dolaba koyarak vakfetmiştir.
} 
göstermektedir. Öz bir ifade ile o dönemde kadınlar toplumda kamu alanında aktif olarak yer aldıkları, zamanın ekonomisinden de gayet iyi anladıkları ortadadır.

Osmanlı kadını malını dilediği gibi kullanma hakkına sahip olması, sadece tüketen değil üreten konumunda toplumdaki rolünü bizatihi ve aktif olarak ifa ederek bulundukları topluma sosyal hizmetler bağlamında katkı sağladıklarını göstermektedir. Diğer bir ifade ile kadın toplum hayatının dışında kalmamıştır. Köylü, şehirli, sultan, cariye gibi birçok statüde karşımıza çıkmaktadır. Tüm bu roller farklı mekânlar ve tarihlerde görülmektedir. Yaşadığı toplumda üretime doğrudan katılarak avrat pazarlarında, bohçacılıkta, imalathanelerde, dokuma tezgâhlarında hep karşımıza çıkmıştır. Her anlamda sosyal bir hizmet vazifesi gören vakıfları sayesinde dönemine yön veren Osmanlı kadını, gelecek dönemlerde de kadına verilen değer ve kadın kimliği adına örnek model olmuştur.

Gerek literatür gerekse defter ve vakfiye örnekleri incelenerek elde edilen veriler göstermektedir ki; Osmanlı kadını vakıflar kurarak toplumsal hayatta yerini almıştır. Elde edilen veriler Osmanlı Kadınının mal ve mülk sahibi olunduğu, girişim ve özgürce tasarruf hakkına sahip olduğu tezini desteklenmektedir. Kurulan her vakfın gelir ve bağışının farklı olması bize hem varlıklı hem de mütevazı hayata sahip birçok kadının vakıf kurduğuna işaret etmektedir. Kadınların kendi kurdukları vakıflar yanında ailelerinden kalan vakıflarda görev alarak idareci rolünü üstlenerek, tayin ettiği mütevelliler için şart koştuğu aylık gelirler ile de işveren statüsünde yer aldıkları anlaşılmaktadır.

Veriler gösteriyor ki, Osmanlı Kadını sosyal sorumluluk projelerinde rol alarak vakıf sayesinde toplumsal süreçlere aktif olarak katılmıştır.

\section{Öneriler}

Vakıf, Buhara'dan Ankara'ya Türk toplumunun zaman ve mekândaki yaşam deneyimidir. $\mathrm{Bu}$, çok boyutlu bir deneyimdir. $\mathrm{Bu}$ araştırma sosyal sorumluluk bağlamında Osmanlı kadınının kamusal alanda rolünü, sosyal hizmet açısından önemini tartışmaktadır. Ancak vakıf kurumunun diğer kültürel boyutları da araştırılmalıdır. Bu bağlamda:

*Genç araştırmacılar teşvik edilmelidir. ilişkiler,

*Vakfın; işletme, sosyal sorumluluk, girişimcilik, dayanışma, iktisat, halkla

İletişim, insan kaynakları, istihdam, meslek, sosyal politika, ulaşım, mimari, lojistik, çevre, geri dönüşüm, şehircilik, kültür vb. açılardan araştırılması için proje destekleri sağlanmalı ve özendirilmelidir.

*Makro, Mikro, Mezzo sosyal hizmet açısından vakıf araştırmaları yapılarak bu kültürel miras güncellenmelidir.

*Günümüz toplumunda kadınlarımıza hemcinsleri olan Osmanlı kadınının yaptığı hayır işleri ile ilgili bilgilendirme çalışmaları (seminer, basılı kaynak vb.) sağlanarak örnek uygulamalara destek olmaları sağlanabilir.

*Toplumda farkındalık çalışmaları yapılarak vakıflarda dikkat çeken kültür 
öğeleri hatırlanmalı; gelenek ve göreneklerinin farkında, onlara sahip çıkan bir neslin yetişmesi hedeflenmelidir.

*Bu bağlamda kadının toplumdaki önemi, değeri ve çalışmalarını konu alan bilgilendirme toplantıları yanında sosyal hizmetlerden akademik alanda farklı projeler beklenmektedir. Hazırlanacak olan yeni projelerde; tarihimizde iz bırakmış önemli vâkıfelerin (Vakıf Kuran Kadınlar) çalışmaları incelenerek örnek uygulamalara rehberlik etmesi sağlanmalıdır.

*Bu konuda çalışmalara ağırlık verilerek özellikle vakıf işletme modelleri ve kadının yönetim ve organizasyonda, ekonomik hayattaki rolü incelenmelidir.

$\mathrm{Bu}$ mütevazı çalışmanın sonuçlarından, Osmanlı kadınının vakıflar aracılığıyla yaptığı sosyal hizmetlere dikkat çekmesi ve Osmanlı kadınının toplumsal rolünü tanıma konusunda merak uyandırması beklenmektedir.

\section{Kaynakça}

Albilal, Rawaa N. (2013). "Vakıf Hayırseverlik Sistemi-Bizi Bağlayan Değer", Dünya Vakıflar Konferansı 23-24 Eylül 2013.(ss. 185-187). İstanbul: T.C. Başbakanlık Vakıflar Genel Müdürlügü.

Alpgüvenç, C. (2010). Hayırda Yarışan Hanım Sultanlar.İstanbul: Kaynak Yayınları.

Any Fay, M. (2000). Kadınlar ve Vakıflar: 18. Yüzyı1 Mısır'ında Mülkiyet, İktidar ve Toplumsal Cinsiyetin Nüfuz Alanı. Madelıne C. Z1lfi(Ed.). Modernleşmenin Eşiğinde Osmanlı Kadınları içinde, (ss.27-40). (Çev. Necmiye Alpay). İstanbul: Tarih Vakfı Yurt Yayınları 111.

Ateş, İ. (1995). "Bursa'da İnegöllüoğlu Saffet Beyin Yaptırdığı Dullarevi”, XII. Vakıf Haftası Kitabı, XII,1995. 25.

Ateş, İ. (1990). Mimar Sinan Vakfi. İstanbul: Türk Dünyası Araştırmaları Vakfı Yayınlar1.

Baş, E. (2006). Arşiv Belgelerinden Hareketle XVIII.y.y. Osmanlı Toplum Hayatında Kadın. Yüksek Lisans Tezi, Marmara Üniversitesi Sosyal Bilimler Enstitüsü, İstanbul, Türkiye.

Başol, S. ve Çam, M. (2010). “Osmanlı Devleti’nde Kadınlara Yönelik Kurulan Vakıflar”, 21. Yüzyılın Eşiğinde Kadınlar -Değişim ve GüçlenmeUluslararası Multidisipliner Kadın Kongresi 13-16 Ekim 2009. (ss. 196205). İzmir.

Berki, Ali H. (2006). "İslamda Vakıf Zağnos Paşa ve Zevcesi Nefise Hatun Vakfiyeleri”, Vakıflar Dergisi, 4, 19-37.

Buturovıç, A. ve Shıck İ.C. (2009). Osmanlı Döneminde Balkan Kadınları Toplumsal Cinsiyet, Kültür, Tarih. (Çev., Güliz Erginsoy). İstanbul: İstanbul Bilgi Üniversitesi Yayınları 257. 
Cunbur, M. (2006). “ÜmmüGülsüm Hatun Vakfiyesi”, Vakıflar Dergisi, 5, 207 212.

Çataltepe, S. (1991). İslam-Türk Medeniyetinde Vaklflar. İstanbul: Türkiye Milli Kültür Vakfi Yayınları.

Davis, F. (2006). Osmanlı Hanımı 1718'den 1918'e Bir Toplumsal Tarih. ( Çev., Bahar T1rnakc1). İstanbul: Yap1 Kredi Yayınları.

Demiryürek, M. (2011). Kıbrıs Şer'iye Sicillerine Göre XVIII. Yüzyılın İlk Yarısında Kıbrıs'ta Kurulan Para Vakıfları (Vakf-1 Nükûd), [Elektronik versiyon]. TurkishStudiesInternational PeriodicalFortheLanguages, LiteratureandHistory of TurkishorTurkic. 6, 941-960.

Duran, T. (Ed.) (1990). Tarihimizde Vakıf Kuran Kadınlar Hanım Sultan Vakfiyeleri. İstanbul: Tarihi Araştırmalar ve Dokümantasyon Merkezleri Kurma ve Geliştirme Vakfı Yayınları.

Eraslan, S. (2011). Kadın Sultanlar. İstanbul: Timaş Yayınları.

Gülsoy, U. (2012). Bir Medeniyetin İzdüşümü Vakıflar. İstanbul: Vakıflar Genel Müdürlüğü Yayınları.

Kazıcı, Z. (1985). İslami ve Sosyal Açıdan Vakıflar, Marifet Yayınları: İstanbul.

Kazıcı,Z. (2005). "Gönüllü Çalışmalarda Kadın"Marmara Üniversitesi Illâhiyat Fakültesi / Diyanet Aylık Dergisi, Ekim, 85-97.

Kavakl1, S. (2012). "1890 ve 1895 Yılları Arasında Gaziantep'in Medrese, Yemek, Su ve Çeşme Vakıfları", Kastamonu Eğitim Dergisi, 20, 313-326.

Köprülü, M.F. (1983). İslam ve Türk Hukuk Tarihi Araştırmaları ve Vakıf Müessesesi. İstanbul: Ötüken Yayınları.

Kunter, H.B. (1939).Türk Vakıflarl ve Vakfiyeleri. İstanbul: Cumhuriyet Matbaasi.

Maydaer, S. (2009). XV. Yüzyılda Bursa'da Hayırsever Bir Çift: Hoca Ece ve Ayşe Hatun'un Vakıfları, [Elektronik versiyon]. Uludağ Üniversitesi Ilâhiyat Fakültesi Dergisi. 1, 495-508.

Mazak,F. (2009). "Mahpeyker Kösem Vâlide Sultan ve Çinili Külliyesi “ Üsküdar Sempozyumu-4, Ağustos 2009. (ss.361-376). İstanbul. Vakiflar Genel Müdürlüğü.

Mazak, F. (2000). Sultan II. Mahmud'un Kızı Âdile Sultan. İstanbul:Çamlıca Kültür ve Yardım Vakfi Yayınları.

Mazak, F. (2004). ”Adile Sultan'ın Üsküdar'da Yaşadığı Mekânlar, Vakıfları Ve Bugünkü Durumları "Üsküdar Sempozyumu-1 Bildiriler. 2.cilt, Ocak 2004. (ss.123-138) İstanbul.

Okudan, M. (2011), "Osmanlı'nın Son Yüzyılında Samsun'da Vakıf Kuran Kadınlar" Ondokuz Mayıs Üniversitesi İlahiyat Fakültesi Dergisi, 31, 267277.

Özlü, Z. (2006). Göynük Kent Merkezinde Bulunan Vakıflar ve Vakıf Görevlileri, [Elektronik versiyon]. EkevAkademi Dergisi. 26,193-208 
Yalova Sosyal Bilimler Dergisi

Özdemir, H. (1998). ”Eyüp Sultan'da Bir Hanım Sultan “Eyüp Sempozyumu, May1s 1998. (s.210-215) İstanbul.

Öztürk,N. (1995). Türk Yenileşme Tarihi Çerçevesinde Vakıf Müessesesi, Ankara: Türkiye Diyanet Vakfı Yayınları.

Pazan, İ. (2011). Padişah Anneleri Eserleriyle Valide Sultanlar, İstanbul: Babıali Kültür Yayıncılığı, 4. Baskı(1.Baskı: 2007).

Sağırlı, A.ve Açıkel, A. (2005). OsmanlıDöneminde Tokat Merkez VakıflarıVakfiyeleri 1. Cilt, Tokat: Gazi Osman Paşa Üniversitesi Fen- Edebiyat Fakültesi Yayınları.

Savcı, K. (1973). Cumhuriyet'in 50. Yılında Türk Kadını, Ankara: Cihan Matbaası.

Singer, A. (2004). Osmanlı'daHayırseverlik Kudüs'te Bir Haseki Sultan Imareti. (Çev. Dilek Şendil). İstanbul: Tarih Vakfı Yurt Yayınları.

Toska,Z. (1999). "İstanbul Hayahânesinde Beliren Kadın Simaları ”, Osmanlı Ansiklopedisi, c.5, Ankara: Yeni Türkiye Yayınları.

Tuncay, A. (1984). Eski Vakıf Hükümlerimiz ve Vakıflarla İlgili Bazı Inceleme ve Sorunlar. İstanbul: Yıldız Sarayı Vakfı Yayınları.

Tuş, M. (2000). "Osmanlılarda Özel Toprak Mülkiyeti ve Vakıf Münasebeti I ", Selçuk Üniversitesi Sosyal Bilimler Enstitüsü̈ Dergisi, 5, 181-196.

Uluçay,M. Ç. (1985). Padişahların Kadınları ve Kızları. Ankara: Türk Tarih Kurumu Basimevi.

Müftüoğlu, M.F. (Ed.) (2012). Tarihte İlginç Vakıflar. Ankara: Vakıflar Genel Müdürlüğü Yayınları:48.

Vakıflar Umum Müdürlügü̈, (1941). Vakıflarımız. İstanbul: Vakıflar Umum Müdürlüğü.

Yazıc1, N. (2007). "Osmanlılarda Yetimlerin Korunmas1 Üzerine Baz1 Değerlendirmeler" Ankara Ü. İlâhiyat Fakültesi-AÜİFD XLVIII, I, 1-46.

Yediyıldız,B. (1982). "Vakıf İncelemelerinde Metod Araştırmaları",2. Vakaf Haftası, II, 16-18.

Yüksel, H. (1999). "Osmanlı Toplumunda Vakıflar Ve Kadın (XVI-XVII. yüzyıllar)", Osmanlı Ansiklopedisi, c.5, Ankara: Yeni Türkiye Yayınları.

Zeyrek Soyer, Ö. (2007). Kadın Vakfflart: Kütahya Örneği (1789 - 1923),Yüksek Lisans Tezi, Kütahya, Türkiye.

http://www.vgm.gov.tr/12.11.2012.

http://www.vgm.gov.tr/dergiler/bimediz/index.html\#/1/05.10.2012.

http://www.zaman.com/mainAction.action,12 Şubat 2010. 